\title{
\#USGS
}

S

Prepared in cooperation with the Bureau of Reclamation

\section{An Assessment of Flow Data from Klamath River Sites Between Link River Dam and Keno Dam, South-Central Oregon}
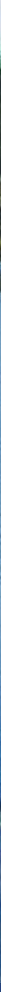

Scientific Investigations Report 2006-5212 
Cover: Klamath River upstream of Keno Dam near Keno , Oregon

(Photograph by John C. Risley, U.S. Geological Survey, October 2005.) 


\section{An Assessment of Flow Data from Klamath River Sites Between Link River Dam and Keno Dam, South-Central Oregon}

By John C. Risley, Glen W. Hess, and Bruce J. Fisher

Prepared in cooperation with the

Bureau of Reclamation

Scientific Investigations Report 2006-5212 


\section{U.S. Department of the Interior \\ DIRK A. KEMPTHORNE, Secretary \\ U.S. Geological Survey \\ P. Patrick Leahy, Acting Director}

\section{U.S. Geological Survey, Reston, Virginia: 2006}

For product and ordering information:

World Wide Web: http://www.usgs.gov/pubprod

Telephone: 1-888-ASK-USGS

For more information on the USGS--the Federal source for science about the Earth, its natural and living resources, natural hazards, and the environment:

World Wide Web: http://www.usgs.gov

Telephone: 1-888-ASK-USGS

Any use of trade, product, or firm names is for descriptive purposes only and does not imply endorsement by the U.S. Government.

Although this report is in the public domain, permission must be secured from the individual copyright owners to reproduce any copyrighted materials contained within this report.

Suggested citation:

Risley, J.C., Hess, G.W., and Fisher, B.J., 2006, An assessment of flow data from Klamath River sites between Link River Dam and Keno Dam, south-central Oregon: U.S. Geological Survey Scientific Investigations Report 2006-5212, $30 \mathrm{p}$. 


\section{Contents}

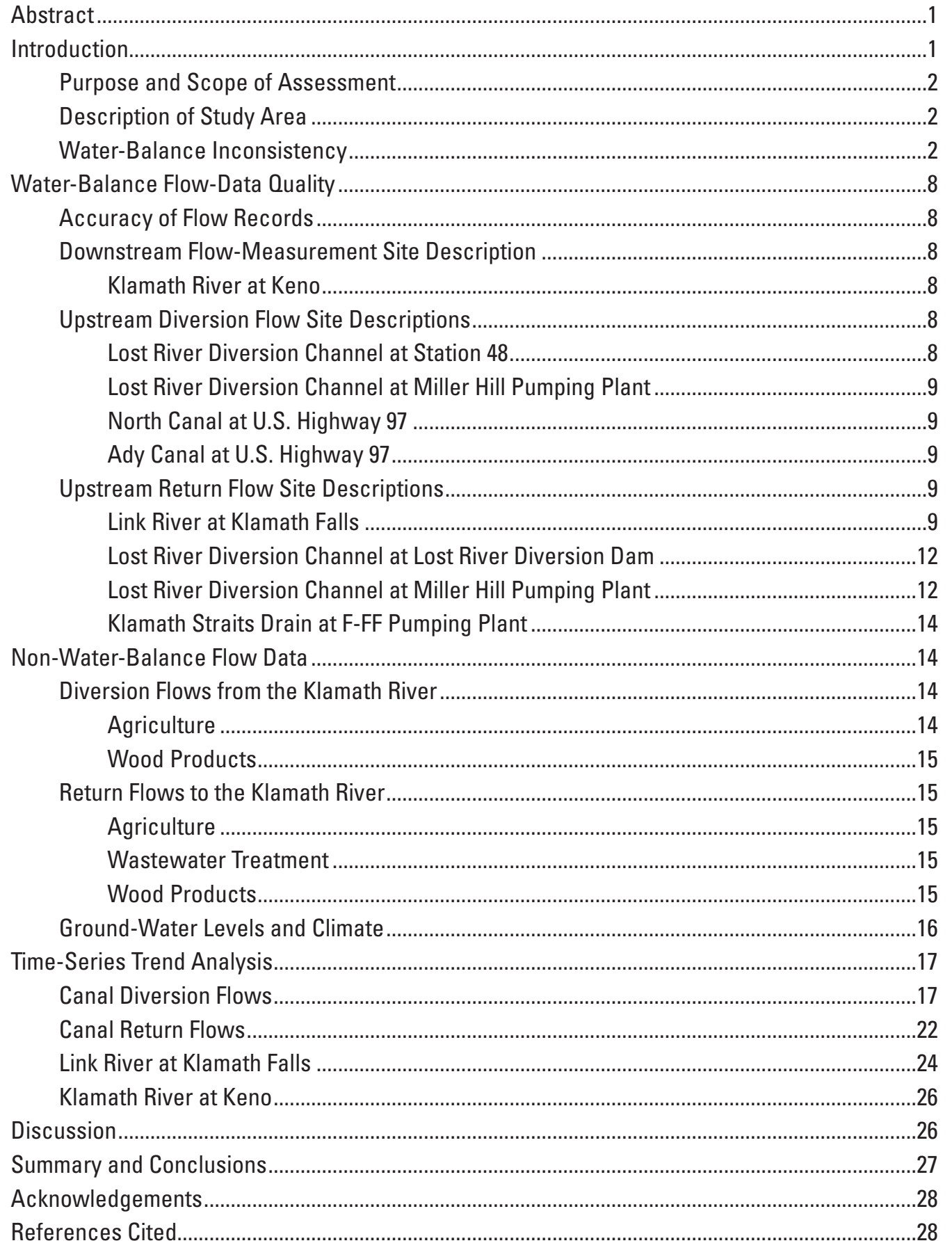




\section{Figures}

Figure 1. Map showing location of the Klamath River-Lake Ewauna study area, in south-central Oregon, the water-balance reach, and flow-measurement sites

Figure 2. Schematic diagram of water-balance reach of the Klamath River, south-central Oregon, showing diversions and return flows used in computing the water balance

Figure 3. Graph showing comparison of April-September net river and canal flows for the water-balance reach of the Klamath River, south-central Oregon, 1961-2004

Figure 4. Diagram showing Link River (headwaters of the Klamath River) and the westside power canal, south-central Oregon

Figure 5. Graph showing April-September net river and canal flows estimated using the USGS flow record for the Link River without westside power canal flow, south-central Oregon, 1961-2004

Figure 6. Graph showing comparison of U.S. Geological Survey and Bureau of Reclamation-PacifiCorp westside power canal flows, south-central Oregon, 1961-2004

Figure 7. Graph showing precipitation for Klamath Falls, south-central Oregon, water years 1961-2004.

Figure 8. Graphs showing monthly flows in four diversion canals, south-central Oregon, water years 1961-2004.

Figure 9. Graphs showing monthly flows in three return-flow canals, south-central Oregon, water years 1961-2004

Figure 10. Graph showing cumulative monthly canal diversion flows for the water-balance reach of the Klamath River, south-central Oregon, water years 1961-2004.

Figure 11. Graph showing cumulative residual monthly canal diversion flows for the water-balance reach of the Klamath River, south-central Oregon, water years 1961-2004.

Figure 12. Graph showing monthly flow for Ady Canal at Stateline Road, south-central Oregon, water years 1961-2004.

Figure 13. Graph showing cumulative monthly canal return flows for the water-balance reach of the Klamath River, south-central Oregon, water years 1961-2004

Figure 14. Graph showing cumulative residual monthly canal return flows for the water-balance reach of the Klamath River, south-central Oregon, water years 1961-2004.

Figure 15. Graph showing cumulative monthly flow at Link River at Klamath Falls, south-central Oregon, water years 1961-2004

Figure 16. Graph showing monthly flow through the "A" Canal at Klamath Falls, south-central Oregon, water years 1961-2004 


\section{Tables}

Table 1. Streamflow-measurement sites on the water-balance reach of the Klamath

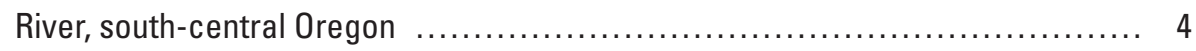

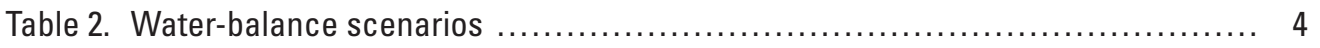

Table 3. Difference between flow at Klamath River at Keno, Oregon and the sum of

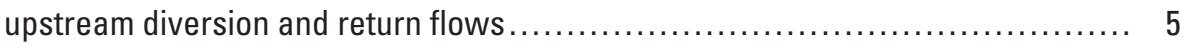

Table 4. Net mean monthly and mean annual flows for the water-balance reach of the Klamath River, south-central Oregon, water years 1961-82 and 1983-2004 .. 7

Table 5. Annual flow records of U.S. Geological Survey and Bureau of Reclamation-PacifiCorp Link River and westside power canal, south-central

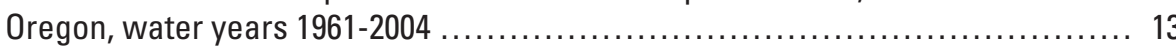

Table 6. Diversion and return flows not used in water-balance calculations for the reach of the Klamath River, south-central Oregon

Table 7. Mean monthly and mean annual diversion flows for the water-balance reach of the Klamath River, south-central Oregon, water years 1961-82 and 1983-2004

Table 8. Mean monthly and mean annual return flows for the water-balance reach of the Klamath River, south-central Oregon, water years 1961-82 and 1983-2004 _.. 23

Table 9. Mean monthly and mean annual flows through the "A" Canal, Klamath Falls, south-central Oregon, water years 1961-82 and 1983-2004

Table 10. Mean monthly and mean annual flows for the Klamath River at Keno, south-central Oregon, water years 1961-82 and 1983-2004 


\section{Conversion Factors, Datum, and Abbreviations}

Conversion Factors

\begin{tabular}{lcl}
\hline \multicolumn{1}{c}{ Multiply } & By & \multicolumn{1}{c}{ To obtain } \\
\hline acre & 0.4047 & hectare \\
acre & 0.4047 & square hectare \\
acre & 0.004047 & square kilometer \\
acre-foot (acre-ft) & 1,233 & cubic meter \\
acre-foot (acre-ft) & 0.001233 & cubic hectometer \\
acre-foot per year (acre-ft/yr) & 1,233 & cubic meter per year \\
acre-foot per year (acre-ft/yr) & 0.001233 & cubic hectometer per year \\
cubic foot per second (ft $3 / \mathrm{s})$ & 0.02832 & cubic meter per second \\
foot (ft) & 0.3048 & meter \\
inch (in.) & 2.54 & centimeter \\
inch (in.) & 25.4 & millimeter \\
million gallons per day (Mgal/d) & 0.04381 & cubic meter per second \\
mile (mi) & 1.609 & kilometer \\
square mile (mi ${ }^{2}$ ) & 2.590 & square kilometer \\
\hline
\end{tabular}

Datum

Horizontal coordinate information is referenced to the North American Datum of 1927 (NAD 27).

Abbreviations

\begin{tabular}{ll}
\hline \multicolumn{1}{c}{ Abbreviation } & \multicolumn{1}{c}{ Definition } \\
\hline Reclamation & Bureau of Reclamation \\
Cal Poly & California Polytechnic State University Irrigation Training and Research Center \\
FERC & Federal Energy Regulatory Commission \\
KDD & Klamath Drainage District \\
KID & Klamath Irrigation District \\
OWRD & Oregon Water Resources Department \\
PC & PacifiCorp \\
RM & river mile \\
SCADA & Supervisory Control and Data Acquistion \\
TID & Tulelake Irrigation District \\
USGS & U.S. Geological Survey \\
WWTP & wastewater treatment plant \\
WY & water year \\
\hline
\end{tabular}




\title{
An Assessment of Flow Data from Klamath River Sites Between Link River Dam and Keno Dam, South-Central Oregon
}

\author{
By John C. Risley, Glen W. Hess, and Bruce J. Fisher
}

\section{Abstract}

Records of diversion and return flows for water years 1961-2004 along a reach of the Klamath River between Link River and Keno Dams in south-central Oregon were evaluated to determine the cause of a water-balance inconsistency in the hydrologic data. The data indicated that the reach was losing flow in the 1960s and 1970s and gaining flow in the 1980s and 1990s. The absolute mean annual net water-balance difference in flows between the first and second half of the 44-year period (1961-2004) was approximately 103,000 acre-feet per year (acre-ft/yr). The quality of the diversion and returnflow records used in the water balance was evaluated using U.S. Geological Survey (USGS) criteria for accuracy. With the exception of the USGS Klamath River at Keno record, which was rated as "good" or "excellent," the eight other flow records, all from non-USGS flow-measurement sites, were rated as "poor" by USGS standards due to insufficient data-collection documentation and a lack of direct discharge measurements to verify the rating curves. The record for the Link River site, the most upstream in the study area, included both river and westside power canal flows. Because of rating curve biases, the river flows might have been overestimated by 25,000 acre-ft/yr on average from water years 1961 to 1982 and underestimated by 7,000 acre-ft/yr on average from water years 1983 to 2004. For water years 1984-2004, westside power canal flows might have been underestimated by 11,000 acre-ft/yr.

Some diversion and return flows (for mostly agricultural, industrial, and urban use) along the Klamath River study reach, not measured continuously and not included in the water-balance equation, also were evaluated. However, the sum of these diversion and return flows was insufficient to explain the water-balance inconsistency.

The possibility that ground-water levels in lands adjacent to the river rose during water years 1961-2004 and caused an increase in ground-water discharge to the river also was evaluated. However, water-level data from local wells did not have a rising trend during the period.
The most likely cause of the water-balance inconsistency was flow measurement error in the eight non-USGS flow records. Part of the water-balance inconsistency can be explained by a 43,000 acre-foot error in the river and canal flow portions of the Link River flow record. A remaining 60,000 acre-foot error might have been distributed among the seven other flow records, or much of the remaining 60,000 acre-foot error might have been in the Link River flow record because flows in that record had a greater magnitude than flows in the seven other records.

As an additional analysis of the water-balance issue, flow records used in the water balance were evaluated for trends and compared to known changes in water management in the Bureau of Reclamation Klamath Project and Lower Klamath and Tule Lake National Wildlife Refuges over the 44-year period. Many of the water-management changes were implemented in the early 1980s. For three diversion flow records, 1983-2004 mean annual flows were 16,000, 8,000 , and 21,000 acre-ft/yr greater than their 1961-82 mean annual flows. Return flows to the Klamath River at two flowmeasurement sites decreased by 31,000 and 27,000 acre-ft/yr for 1983-2004 compared with the 1961-82 period.

\section{Introduction}

In December 2004, the USGS provided a hydrologic assessment of the Klamath Basin Water Bank Program for the Bureau of Reclamation (Reclamation) Klamath Basin Area Office (U.S. Geological Survey, written commun., 2005). In the assessment, inconsistencies were found in the river and canal flow records from sites along the Klamath River between Klamath Falls and Keno, Oregon, for 1961-2004. A simple water balance estimated from the records indicated that the Klamath Falls to Keno reach was a losing reach in the 1960s and 1970s and a gaining reach in the 1980s and 1990s. However, ascertaining the cause of these flow inconsistencies was not possible because of the limited scope and time available for the water-bank assessment. The inconsistencies prompted the following questions: 
- Were the inconsistencies the result of flow-data collection error? If so, which streamflow-measurement sites contributed most of the error?

- Were the inconsistencies caused by changes in undocumented diversion and return flows during the 44-year period?

- Were the inconsistencies the result of rising groundwater levels and/or changes in climate trends?

- Were the inconsistencies the result of a combination of causes?

\section{Purpose and Scope of Assessment}

As a result of these unanswered questions, Reclamation requested that the USGS perform a more in-depth analysis of historic and current Klamath Project diversion and return-flow data in order to accurately quantify uncertainty in the data and the benefits of the water-bank operations.

The scope of this assessment was limited to the streamflow-measurement sites directly related to diversion and return flows to and from the Klamath River reach between the Link River at Klamath Falls and Klamath River at Keno sites. The "A" Canal is not in this reach of the Klamath River and therefore was not included in the water balance.

The assessment included:

- An evaluation of flow-data quality for the records used in the water balance

- An analysis of undocumented diversion and return flows in the study reach that were not used in the water balance

- A trend analysis of diversion and return-flow records

\section{Description of Study Area}

The assessment study area, also termed "water-balance reach" in this report, is located near Klamath Falls in southcentral Oregon (fig. 1). The study area extends from the USGS streamflow-gaging station on the Link River at Klamath Falls (11507500) to the USGS gaging station on the Klamath River at Keno (11509500). The Link River is a short river linking Upper Klamath Lake with Lake Ewauna. Lake Ewauna extends from Klamath Falls about 2 mi downstream before it becomes the Klamath River. The flow-measurement site at the lower end of the study area (RM 231.9) is about $1.5 \mathrm{mi}$ downstream of the Keno Dam.
The Klamath Project provides irrigation water to about 240,000 acres and to the Lower Klamath and Tule Lake National Wildlife Refuges (Bureau of Reclamation, 2000; 2006). Streamflow-measurement sites assessed in this report are a subset of the sites in the Klamath Project. However, these sites were selected because the water-bank assessment (U.S. Geological Survey, written commun., 2005) identified concerns about their accuracy and therefore the accuracy of measured flows to and from the Klamath River in the water-balance reach. The reach also includes non-Klamath Project diversion and return flows associated with agriculture, municipal wastewater, and the wood-products industry in the study reach. The possible influence of these flows on our understanding of Klamath River discharge in the reach also was assessed in this study.

\section{Water-Balance Inconsistency}

The sum of the inflows and outflows measured at eight sites was used to compute a surface-water balance for the reach of the Klamath River between Link River Dam and Keno Dam (table 1, fig. 2). The resulting calculated net flow was then subtracted from flow at the USGS measurement site at Keno (11509500) to determine whether the reach was losing or gaining. Flow at the four diversion and four return flow-measurement sites were negative and positive terms in the water balance, respectively. If all inflows to and outflows from the reach could be accurately documented and measured, the right side of the equation shown below $\left(Q_{\text {residual }}\right)$ would be zero (table 2). However, if that condition is not met and the right side of the equation is nonzero, a gaining reach will have a positive value and a losing reach will have a negative value. Flow-measurement errors can result in a false characterization of a reach as gaining or losing.

$$
\begin{aligned}
& Q_{\text {downstream_oufflow }} \\
& \quad-\left(Q_{\text {upstream_inflows }}-Q_{\text {upstream_outflows }}\right)=Q_{\text {residual }}
\end{aligned}
$$

where:

$$
\begin{gathered}
Q_{\text {downstream_ouflow }} \text { is the flow at the downstream Klamath } \\
\text { River streamflow-gaging station at Keno, } \\
Q_{\text {upstream_inflows }} \text { is the sum of upstream inflows, } \\
Q_{\text {upstream_outflows }} \text { is the sum of upstream outflows, and } \\
Q_{\text {residual }} \text { is the unaccounted for gain or loss in flow } \\
\text { for the reach. }
\end{gathered}
$$

The Klamath Project flow-measurement sites are operated by Reclamation and irrigation and drainage districts. The Link River flow data used in the analysis were compiled by PacifiCorp and Reclamation. The Klamath River at Keno streamflow-gaging station (11509500) is operated by the USGS. Monthly flow records from all sites were used to compute the monthly net sum water balance (table 3). 


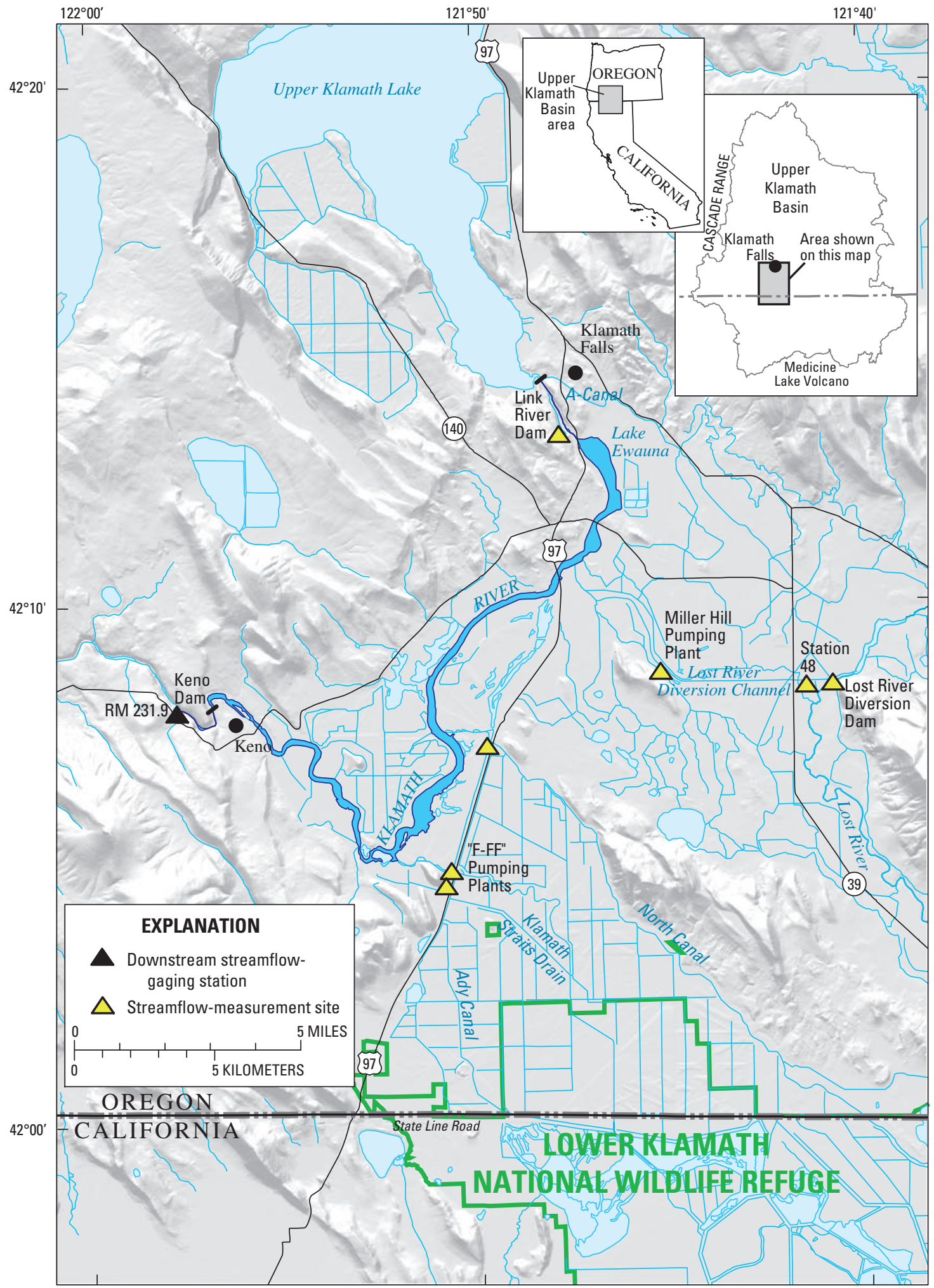

Base from U.S. Geological Survey digital data, 1:24,000 and 1:100,000 Universal Transverse Mercator projection, Zone 13.

Datum is North American Datum of 1927

Figure 1. Location of the Klamath River-Lake Ewauna study area, in south-central Oregon, the waterbalance reach, and flow-measurement sites. 
Table 1. Streamflow-measurement sites on the water-balance reach of the Klamath River, south-central Oregon.

[Location of streamflow-measurement sites are shown in figure 1. Mean annual flow: Based on 1961-2004 period. Accuracy ratings: Both are defined as the percentage of error $( \pm)$ in actual flow of 95 percent of daily flows. USGS: Based on water year 2004 record. Cal Poly: Based on water years 1999 and 2000 records. Abbreviations: Reclamation, Bureau of Reclamation; Cal Poly, California Polytechnic State University Irrigation Training and Research Center; KDD, Klamath Drainage District; KID, Klamath Irrigation District; PC, PacifiCorp; TID, Tulelake Irrigation District; USGS, U.S. Geological Survey. Symbol: >, greater than]

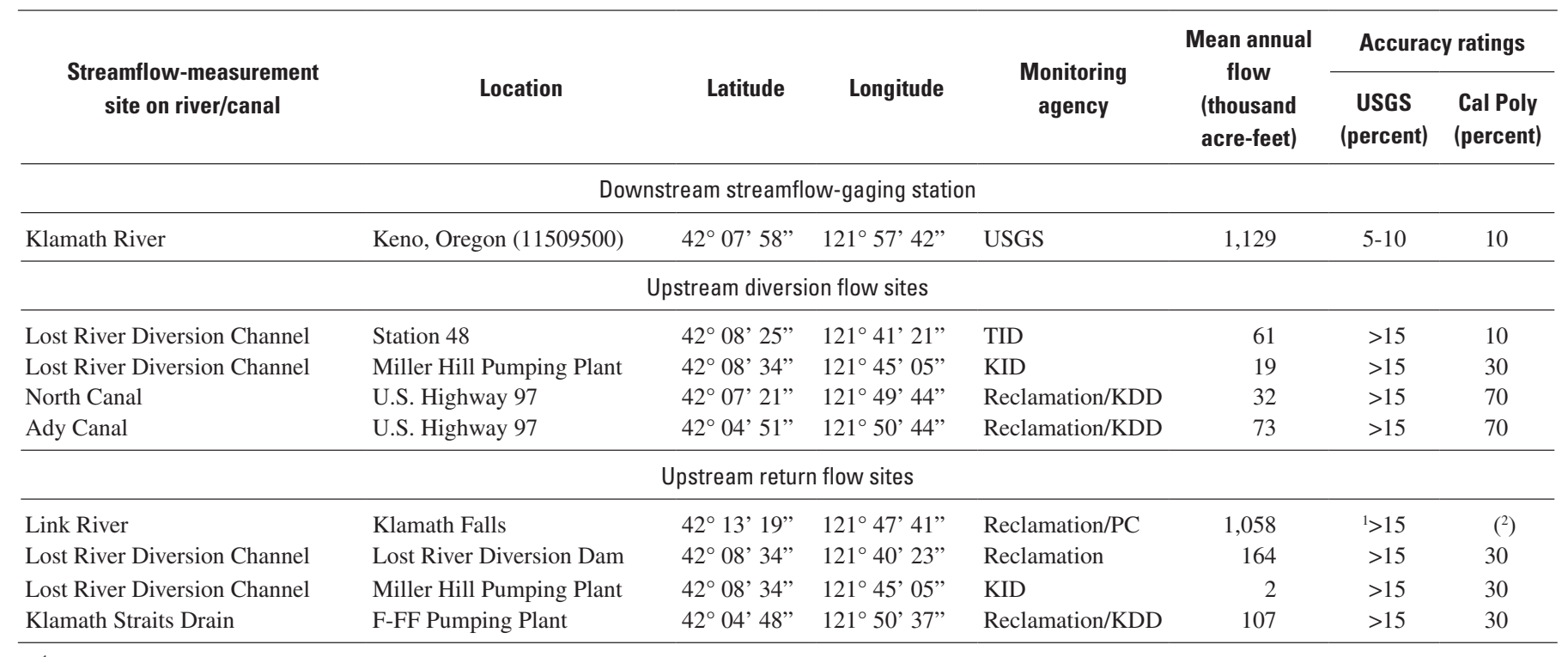

${ }^{1}$ Rating for the Reclamation-PacifiCorp version of this record not the USGS version.

${ }^{2} \mathrm{Cal}$ Poly did not evaluate the Reclamation-PacificCorp version of the flow record.

Table 2. Water-balance scenarios.

Case 1: No unaccounted gains or losses

$Q_{\text {downstream_outflow }}-\left(Q_{\text {upstream_inflow }}-Q_{\text {upstream_outflow }}\right)=0$

Case 2: Gaining stream

$Q_{\text {downstream_outflow }}-\left(Q_{\text {upstream_inflow }}-Q_{\text {upstream_outflow }}\right)>0$

Possible reasons:

1. Unaccounted ground-water inflow

2. Other unaccounted inflows not included in the water balance

3. Measurement error

Measured upstream inflows less than actual value

Measured upstream outflows greater than actual value

Measured downstream outflows greater than actual value

Case 3: Losing stream

$Q_{\text {downstream_outflow }}-\left(Q_{\text {upstream_inflow }}-Q_{\text {upstream_outflow }}\right)<0$

Possible reasons:

1. Unaccounted outflow to ground water

2. Other unaccounted outflows not included in the water balance

3. Measurement error

Measured upstream inflows greater than actual value

Measured upstream outflows less than actual value

Measured downstream outflows less than actual value 
Table 3. Difference between flow at Klamath River at Keno, Oregon and the sum of upstream diversion and return flows.

[Water year: October 1 to September 30. Link River at Klamath Falls and Klamath River at Keno flows are included in the computation. Values in thousand acre-feet]

\begin{tabular}{|c|c|c|c|c|c|c|c|c|c|c|c|c|c|}
\hline $\begin{array}{c}\text { Water } \\
\text { year }\end{array}$ & Oct. & Nov. & Dec. & Jan. & Feb. & March & April & May & June & July & August & Sept. & Annual \\
\hline 1961 & 0 & 3 & 6 & 0 & 6 & 3 & -4 & -21 & -8 & -14 & -10 & -5 & -44 \\
\hline 1963 & -5 & -6 & -9 & -10 & 0 & -8 & -2 & -7 & -10 & -12 & -9 & -7 & -86 \\
\hline 1964 & -5 & -7 & -11 & -11 & -5 & 2 & -6 & -6 & -4 & -10 & -10 & -8 & -82 \\
\hline 1965 & -10 & -2 & -24 & -51 & -30 & 17 & 4 & -8 & -6 & -11 & -8 & -10 & -140 \\
\hline 1968 & -2 & -5 & -6 & -3 & -1 & -40 & -6 & -8 & -7 & -9 & -7 & -7 & -101 \\
\hline 1969 & -3 & 0 & 0 & 0 & 0 & 4 & 4 & -13 & -6 & -11 & -13 & -8 & -44 \\
\hline 1970 & -2 & -7 & 0 & -4 & 3 & -2 & -5 & -7 & -8 & -11 & -13 & -8 & -62 \\
\hline 1971 & -5 & -2 & -2 & 1 & -4 & 0 & 5 & -3 & -10 & -11 & -12 & -8 & -52 \\
\hline 1972 & -3 & -6 & -6 & -1 & -2 & -1 & -2 & -13 & -13 & -14 & -10 & -6 & -76 \\
\hline 1977 & -1 & -10 & -5 & -2 & -2 & -2 & -6 & -7 & -25 & -24 & -15 & -9 & -107 \\
\hline 1978 & -6 & -3 & 4 & 3 & -3 & -1 & -8 & -7 & -10 & -14 & -11 & 1 & -56 \\
\hline 1979 & -8 & -4 & 0 & 2 & 3 & 3 & 0 & -8 & -9 & -8 & -7 & -6 & -44 \\
\hline 1980 & 0 & 3 & 5 & 6 & 9 & 4 & -1 & -6 & -7 & -8 & -9 & -4 & -7 \\
\hline 1981 & -2 & -1 & 3 & 2 & 5 & 4 & -1 & -7 & -8 & -7 & -10 & -8 & -30 \\
\hline 1982 & 2 & 8 & 14 & 1 & 3 & -4 & 0 & -18 & -7 & -6 & -5 & -5 & -16 \\
\hline 1983 & -3 & -15 & 0 & 3 & 12 & 9 & 2 & -6 & -4 & -4 & -1 & 3 & -3 \\
\hline 1984 & 3 & 12 & 27 & 18 & 19 & 14 & 13 & -2 & 0 & -2 & -2 & 6 & 105 \\
\hline 1985 & 21 & 24 & 18 & 11 & 8 & 13 & 13 & 1 & 0 & -6 & -3 & 3 & 104 \\
\hline 1986 & 5 & 8 & 8 & 6 & 18 & 11 & 1 & 0 & -3 & -3 & 1 & 3 & 55 \\
\hline 1987 & 14 & 6 & 5 & 7 & 4 & 6 & -10 & -4 & -3 & -1 & 3 & 2 & 28 \\
\hline 1996 & -30 & -6 & 9 & 11 & 6 & 4 & -3 & -6 & -4 & 1 & 0 & -8 & -24 \\
\hline 1997 & -5 & 2 & 10 & 20 & 4 & 0 & 3 & -2 & 0 & 0 & -4 & 0 & 28 \\
\hline 1998 & 1 & 6 & 14 & 26 & 22 & 18 & 9 & -5 & 3 & 7 & 7 & 1 & 109 \\
\hline 1999 & 4 & 14 & 6 & 11 & 12 & 17 & 10 & 0 & 3 & -4 & 2 & -5 & 71 \\
\hline 2000 & 0 & 8 & 9 & 3 & 2 & 5 & 1 & -1 & -4 & -1 & -2 & -9 & 12 \\
\hline 2001 & 1 & 3 & 3 & 6 & 3 & 4 & 5 & -1 & -3 & -4 & -5 & 0 & 14 \\
\hline 2002 & 1 & 4 & 2 & -7 & 10 & 6 & 5 & -1 & -4 & -4 & -3 & -1 & 8 \\
\hline 2003 & 3 & 1 & 4 & 8 & 3 & 5 & -1 & -3 & -5 & -4 & -2 & -3 & 6 \\
\hline 2004 & 2 & 7 & 4 & 3 & 5 & 5 & 2 & -2 & -5 & -6 & -9 & -6 & -2 \\
\hline
\end{tabular}




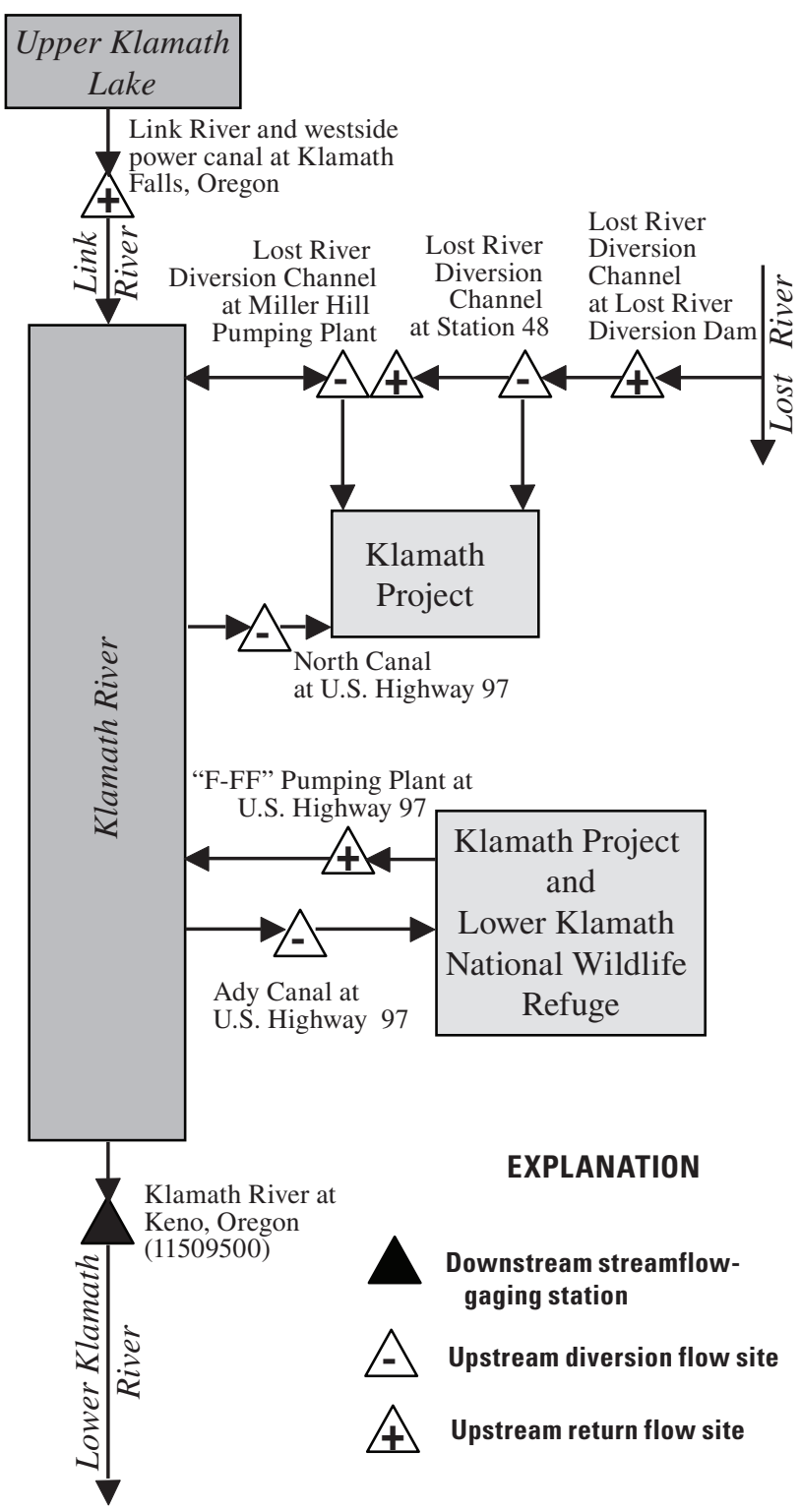

Figure 2. Water-balance reach of the Klamath River, south-central Oregon, showing diversions and return flows used in computing the water balance.

All flow data used in the water-balance analysis came from Reclamation's hydrologic database with the exception of the USGS Klamath River at Keno (11509500) flow record. All flow records spanned 44 years (1961-2004), except for the Miller Hill Pumping Plant return flow record, which began in water year 1987. (A water year is defined as the 12-month period from October 1 to September 30.)
For most months of the year, water in Lost River Diversion Channel flows toward the Klamath River. During the summer, the flow can be reversed when water is diverted from the Klamath River. Until recently, there has not been a gaging station on the Lost River Diversion Channel close to the Klamath River. Four streamflow-measurement sites (Station 48, Miller Hill Pumping Plant diversions, Miller Hill Pumping Plant return spills, and Lost River Diversion Dam), all located on the Lost River Diversion Channel, were included in the water-balance equation to compute the net flow of Lost River Diversion Channel.

As shown in table 3, there is a trend in net Klamath River flows from negative to positive values. Positive values indicate a gain to the Klamath River in the water-balance reach and negative values indicate a loss of water in the reach. In the 1960s and 1970s, most of the values were negative for October through April, indicating a net loss from the river. In the 1980s and 1990s, almost all values for these months are positive, indicating a net gain to the river. Likewise, many values for May-September changed from double digit negative to single digit negative. The inconsistency is also evident in figure 3 , which shows a relation between the sum of April-September net canal flows and April-September net river flows used in the water balance. Net canal flows were calculated as the sum of the diversion flows minus the sum of the return canal flows. Specifically, these include the North Canal, Ady Canal, Miller Hill Pumping Plant, and Station 48 diversion flows minus the Lost River Diversion Dam, Miller Hill Pumping Plant spills, and Klamath Straits Drain F-FF Pumping Plant return flows. Net river flows were computed as Klamath River at Keno flows minus Link River flows.

In figure 3, data points for the first and second 22year periods (1961-82 and 1983-2004) are separated by a regression line that was computed from data for the entire period. Such a sharp separation or shift for the two time periods is an indication of flow data error or changes in undocumented flows that were not included in the water balance. If there were no water-balance inconsistency over the 44-year period, data points from the first and second 22-year periods would be more evenly distributed on both sides of the regression line. Mean monthly and mean annual net waterbalance flow volumes in thousand acre-feet are shown for the two 22-year periods in table 4 . The mean annual net water balance for the first and second 22-year periods (1961-82 and 1983-2004) are about $-68,000$ and 35,000 acre-ft, respectively. The absolute difference between the two periods is about 103,000 acre-ft/yr. 


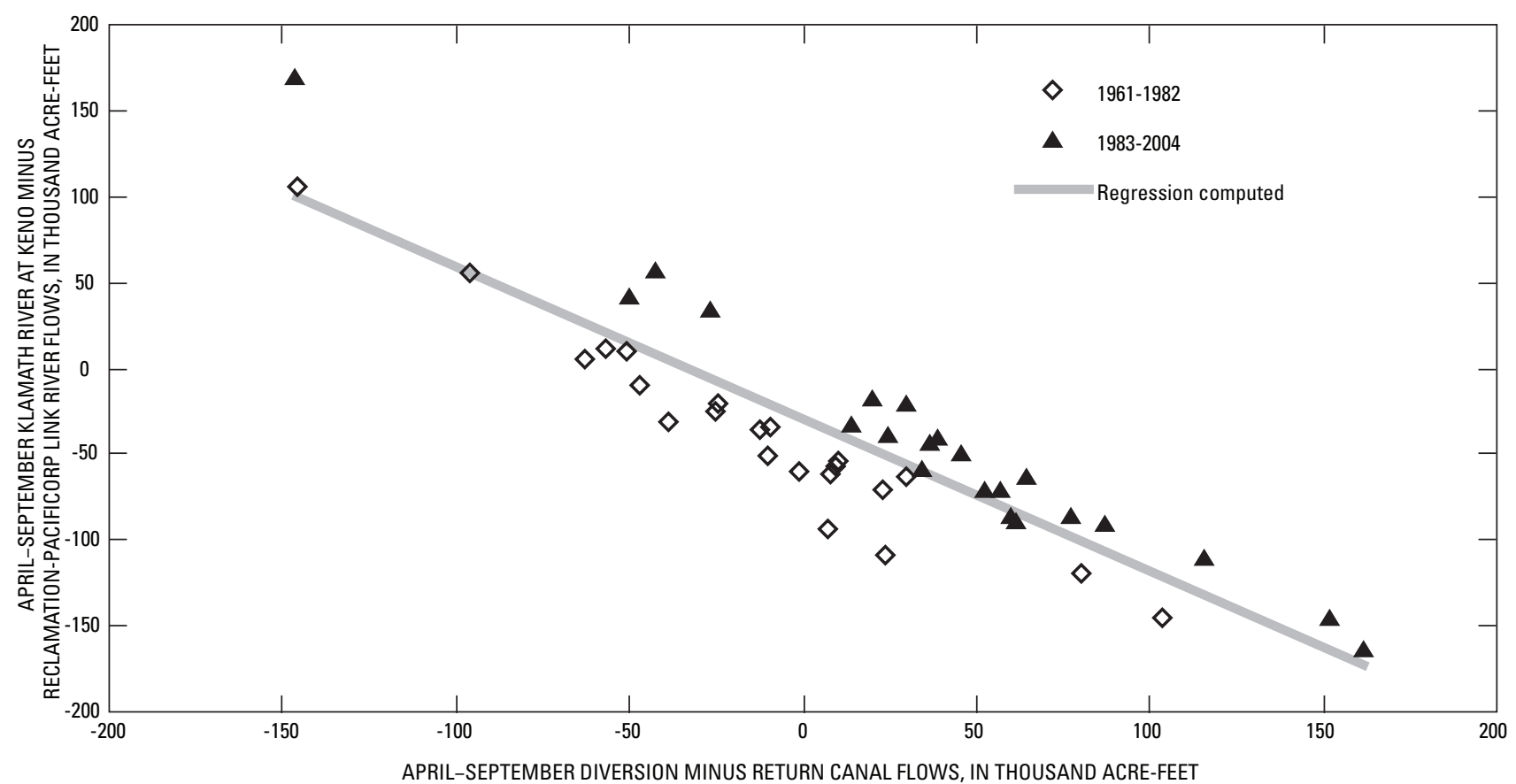

Figure 3. Comparison of April-September net river and canal flows for the water-balance reach of the Klamath River, south-central Oregon, 1961-2004.

Table 4. Net mean monthly and mean annual flows for the waterbalance reach of the Klamath River, south-central Oregon, water years 1961-82 and 1983-2004.

[Values in thousand acre-feet]

\begin{tabular}{lccc}
\hline \multicolumn{1}{c}{ Month } & $\mathbf{1 9 6 1 - 8 2}$ & $\mathbf{1 9 8 3 - 2 0 0 4}$ & $\begin{array}{c}\text { Absolute } \\
\text { difference }\end{array}$ \\
\hline October & -4.02 & 1.42 & 5.44 \\
November & -3.33 & 4.60 & 7.93 \\
December & -3.22 & 7.28 & 10.49 \\
January & -4.34 & 8.51 & 12.85 \\
February & -.98 & 8.35 & 9.33 \\
March & -.48 & 9.61 & 10.09 \\
April & -3.42 & 4.68 & 8.10 \\
May & -9.93 & -1.37 & 8.57 \\
June & -10.12 & -2.07 & 8.05 \\
July & -11.72 & -3.23 & 8.50 \\
August & -9.88 & -1.62 & 8.26 \\
September & -6.81 & -1.41 & 5.40 \\
\cline { 2 - 4 }$\quad$ Annual & -68.25 & 34.75 & 103.01 \\
\hline
\end{tabular}




\section{Water-Balance Flow-Data Quality}

Flow-measurement sites were visited to assess site conditions and methods used. Documentation for the flow measurements also was reviewed. The flow-measurement sites and records used in the water balance were assessed during two field visits by USGS personnel in May and June 2005. At Reclamation's Klamath Basin Area Office, archived files and original documents pertaining to many of the sites were reviewed. Additional files pertaining to these sites also were examined in the Klamath and Tulelake Irrigation District offices. The USGS measurement site on the Klamath River at Keno is operated using standard USGS protocols, and the data are published annually in the USGS annual data report of streamflow data.

\section{Accuracy of Flow Records}

Flow records for the non-USGS measurement sites were not compiled, reviewed, or published on an annual basis. An annual station analysis for these sites was limited or nonexistent. Check measurements of streamflow and instrument maintenance at the sites were not done or documented on a regular basis. Overall data documentation was limited, and a complete paper trail detailing how every daily flow value was computed could not be established. Daily values at these sites were not computed from unit (hourly) values. Flow at some of the canal sites was estimated using a canal weir equation that used the head difference between upstream and downstream head gates. Although continuous strip charts were used at some of the sites to estimate canal stage differences, only a single head-difference value was measured from the charts for each day. At some of the other sites, where stage differences were not measured, a daily flow estimate was based on the time duration of flow passing through a specific gate opening or the time duration of one or more pumps in operation.

The rating that the USGS uses to describe the accuracy of an annual streamflow record depends on (1) the stability of the stage-discharge relation or, if the control is unstable, the frequency of flow measurements, and (2) the accuracy of measurements of stage and flow, and interpretation of records. Accuracy ratings of "excellent" indicate that about 95 percent of the daily flow are within 5 percent of the actual value; "good," within 10 percent; and "fair," within 15 percent (table 1). Records that do not meet these criteria are rated "poor." Accuracy ratings for USGS flow records for a given year are shown in the USGS annual data report for that year. The accuracy rating is applied to a record on an annual basis and can sometimes change from year to year.
In this study, eight of the nine flow records were nonUSGS records. Because documentation for all eight flow records was limited, a reliable paper trail that would show with certainty how every daily flow value was determined could not be established. Because of incomplete documentation, all non-USGS flow records were rated as "poor" by USGS standards (table 1). In addition to the USGS ratings, accuracy ratings (table 1) were assigned by the California Polytechnic State University Irrigation Training and Research Center (Cal Poly) (Burt and Freeman, 2003). Reclamation is in the process of improving measurement methods, accuracy, and documentation of the non-USGS gaging stations described in this report in cooperation with, and as a result of, a network analysis by Cal Poly and the USGS.

\section{Downstream Flow-Measurement Site Description}

\section{Klamath River at Keno}

The daily flow record for the USGS Klamath River at Keno streamflow-gaging station (11509500) began in 1929. For water years 1961-82, the annual records were consistently rated as "good." For water years 1983-92 and 1993-2004, the annual records were rated as "excellent" and "good," respectively.

\section{Upstream Diversion Flow Site Descriptions}

The following flow-measurement sites were used to measure water being diverted away from the water-balance reach of the Klamath River.

\section{Lost River Diversion Channel at Station 48}

Located on the Lost River Diversion Channel, Station 48 diverts water by gravity from the diversion channel into a canal that flows into the natural Lost River (fig. 2). From there, water flows to the Anderson-Rose Dam and eventually to the Tule Lake National Wildlife Refuge, about 20 miles southeast of Klamath Falls. The Tulelake Irrigation District (TID) operates the Station 48 gates by radiotelemetry and also manually monitors and records flow. Daily flow values, in cubic feet per second $\left(\mathrm{ft}^{3} / \mathrm{s}\right)$, are called in daily to Reclamation's Klamath Basin Area Office. Daily flow is computed using a step rating table of gate-opening size and flow. The duration of an opening also is recorded. Upstream stage measurements are not used in the flow computation because flows through the Station 48 gates are only a small 
part of total flow in the Lost River Diversion Channel. Water levels in the diversion channel are assumed to be reasonably constant. The gate size opening and flow rating table are in increments of $50 \mathrm{ft}^{3} / \mathrm{s}$. The maximum flow rate capacity is 550 $\mathrm{ft}^{3} / \mathrm{s}$. The rating table was developed by Reclamation when Station 48 was constructed in 1948. Whether this rating has ever been updated or whether check measurements have ever been made could not be determined (Jerry Pyle, Tulelake Irrigation District, oral commun., June 22, 2005). Because of these factors and limited data documentation, this flow record was rated as "poor."

\section{Lost River Diversion Channel at Miller Hill Pumping Plant}

The Miller Hill Pumping Plant is operated by the Klamath Irrigation District (KID) and has three single speed $35-\mathrm{ft}^{3} / \mathrm{s}$ pumps (maximum total capacity, $105 \mathrm{ft}^{3} / \mathrm{s}$ ) that lift water from the Lost River Diversion Channel into nearby lateral canals. The plant was constructed in 1941 and originally had two pumps. The third pump was added in the mid-1960s. Daily flow is computed by KID by multiplying the number of pumps in operation times $35 \mathrm{ft}^{3} / \mathrm{s}$ and the duration of operation. These daily flows are then sent weekly to Reclamation's Klamath Basin Area Office. Check measurements by Cal Poly (Burt and Freeman, 2003) were within 15 percent of $35 \mathrm{ft}^{3} / \mathrm{s}$ for all three pumps. However, whether other check measurements had been made over the past 44 years could not be determined. A constant rate of $35 \mathrm{ft}^{3} / \mathrm{s}$ was assumed to have been used for each pump in all computations for the entire flow record. Because of these factors and limited data documentation, this flow record was rated as "poor."

\section{North Canal at U.S. Highway 97}

The North Canal gates, near U.S. Highway 97, are used to control flow diversions from the Klamath River to farmlands managed by the Klamath Drainage District (KDD) and Area K Leaselands managed by the Lower Klamath National Wildlife Refuge. (The North Canal in this study should not be confused with the nearby North Canal in the Langell Valley.) The gates are operated by the KDD, but usually are left open. Because the terrain is flat, lateral diversions from the canal at downstream locations operate as a flow control. Opening and closing downstream lateral diversion canals alters the stage-discharge relation at the streamflow-measurement site by creating variable backwater conditions. Flow at the U.S. Highway 97 gate is monitored by Reclamation with two (upstream and downstream)
Stevens ${ }^{\circledR}$ drum recorders mounted on stilling wells. The stage difference is used to compute velocity. Discharge is computed by multiplying velocity times the total gate opening area and a coefficient of discharge. The canal has a low gradient, and stage differences were measured at $\pm 0.1 \mathrm{ft}$. (At a USGS streamflow-gaging station, stage is measured at $\pm 0.01 \mathrm{ft}$.) There was no evidence that levels or check measurements had been made at this site in recent years. During a site visit, one of the staff gages was entirely above water. Also, the gate opening was obstructed by trash and debris jams, which could have affected the water elevations. Because of these factors and limited data documentation, this flow record was rated as "poor."

\section{Ady Canal at U.S. Highway 97}

The Ady diversion canal gates also are located near U.S. Highway 97 . The gates are operated by the KDD, but usually are left open. Similar to North Canal, flow rates are controlled by downstream lateral canal openings. The Ady Canal flow is monitored by Reclamation with two (upstream and downstream) Stevens ${ }^{\circledR}$ drum recorders mounted on stilling wells. This canal has a low gradient, and stage differences were measured at only $\pm 0.1 \mathrm{ft}$. There was no evidence that levels or check measurements had been made at this site in recent years. During a site visit, the gates were found to be obstructed by trash and debris jams and there were several sets of staff gages. Because of these factors and limited data documentation, this flow record was rated as "poor."

\section{Upstream Return Flow Site Descriptions}

The flow-measurement sites discussed in this section measure waters being returned to the water-balance reach of the Klamath River. The flow record for Link River at Klamath Falls is included as a return-flow record because it is a positive term in the water-balance equation. During particularly large winter and spring runoff events, the Lost River Diversion Channel and the Klamath Straits Drain are used to discharge water to the Klamath River to decrease flooding in the Klamath Project and the Lower Klamath and Tule Lake National Wildlife Refuges.

\section{Link River at Klamath Falls}

The USGS has collected flow data at Link River at Klamath Falls (11507500) throughout the period of interest for this study (1961-2004). This streamflow-gaging station, in addition to others in the upper Klamath Basin, is cooperatively funded by PacifiCorp as a part of their license compliance 
with the Federal Energy Regulatory Commission (FERC). Up until (and including) water year 1983, flows in the westside power canal were included in the published USGS record for Link River. However, for water year 1984 (and thereafter) PacifiCorp discontinued the USGS canal flow data collection function of the site. As a result, only river flows have been included in the published USGS record (water years 1984-2005). The westside power canal diverts water from the Link River Dam and bypasses the USGS Link River gaging station. Water in the canal then flows through a powerplant before it is returned to the river downstream of the USGS gaging station (fig. 4).

Although PacifiCorp has funded USGS data collection for the Link River flow record since 1984, they have also made their own estimates of daily flow for the Link River and westside power canal. This was necessary because PacifiCorp needed the data on a real-time basis for power generation operations. (Real-time USGS flow data for this site have been available on the Web only in recent years.) PacifiCorp flow estimates were for their internal purposes and were never intended to be used by the public. PacifiCorp estimated the river portion of the Link River flow record by using USGS stage readings and their own stage-discharge rating curves. They estimated flow in the canal on the basis of

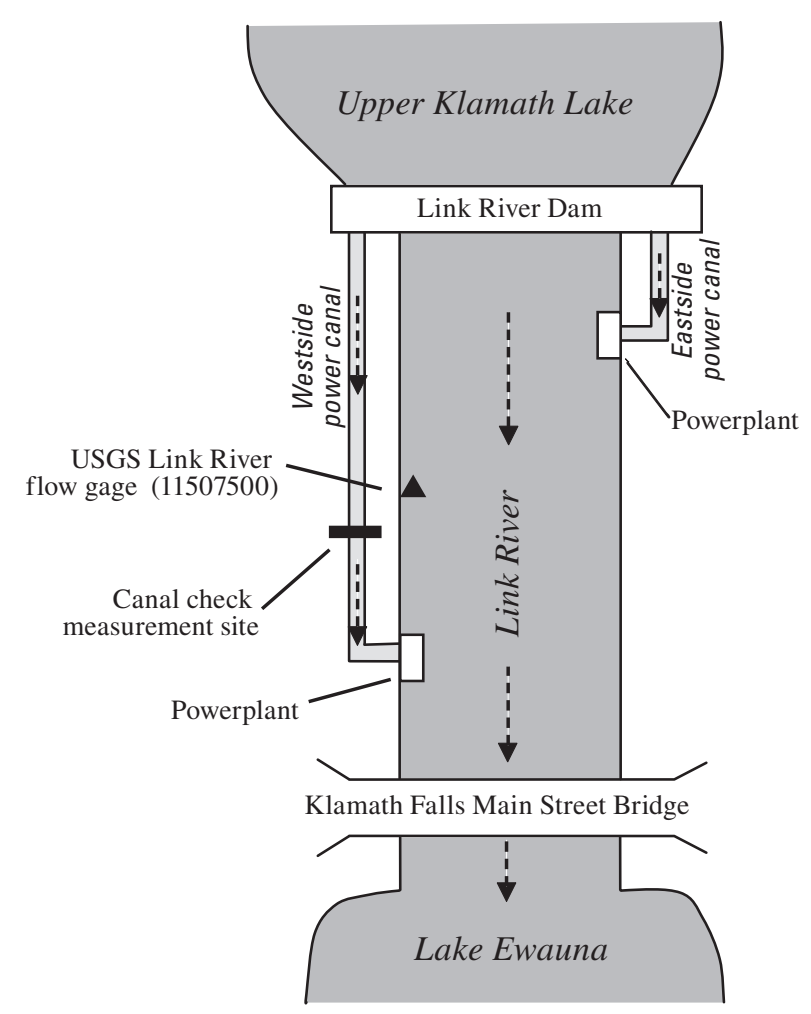

Figure 4. Link River (headwaters of the Klamath River) and the westside power canal, south-central Oregon. the powerhouse intake capacity and the frequency of power production. Because the PacifiCorp Link River flow data were real-time, and the USGS Link River flow data were not realtime until recently, Reclamation had to use PacifiCorp Link River flow data (combined river and canal) for their watermanagement operations. As a consequence, PacifiCorp Link River flow data were input to the Reclamation hydrological database and were also used in the calculation of monthly Upper Klamath Lake net inflow.

For water years 1961-84, the USGS Link River flow records were rated in the annual USGS water-data report as "good." For water years 1985-90 and 1991-2004, flow records were rated as "excellent" and "good," respectively. To test the possibility that non-USGS flow data could be a factor in the inconsistency shown in figure 3 , that graph was modified using USGS Link River flow (river portion only) for the entire period 1961-2004 (fig. 5). In the modified version of the graph, data from the two periods are not sharply separated by the regression line. Less separation could indicate better data-collection consistency. The canal and river components of that record were evaluated separately to assess the extent of potential data error in Reclamation-PacifiCorp flow record for Link River.

Figure 6 shows a comparison of USGS and ReclamationPacifiCorp westside power canal flows for 1962-2004. (The USGS daily flow record for water year 1961 was not available.) The hydrograph shows an abrupt change occurring in the mid-1980s. The USGS and Reclamation-PacifiCorp estimated daily flows were based on different rating curves that related flow to daily power production. The USGS rating curve was continually adjusted and updated every 3 months using check measurements. To develop the rating curve, the USGS made regular check measurements on the canal from a location about $300 \mathrm{ft}$ upstream of the powerplant intake (fig. 4). The Reclamation-PacifiCorp maximum flow rate was based on the powerplant intake rate of $220 \mathrm{ft}^{3} / \mathrm{s}$. The USGS check measurements are a more accurate measurement of canal flow because they were made at a location closer to the gaging station on the river. The Reclamation-PacifiCorp maximum flow rate does not take into account canal leakage, a small agricultural diversion, and spillway flow losses that occur between the USGS gaging station and the powerplant.

Although the canal daily flows were no longer published in the USGS record for Link River after water year 1983, check measurements were still made by the USGS on the canal every 3 months in the years since. The USGS continued to make the canal measurements because they must be subtracted from the river check measurements to make a direct comparison to the USGS Link River gaging station (fig. 4). The river check measurements are made from the Klamath Falls Main Street Bridge, which is downstream of the canal and the powerplant. 


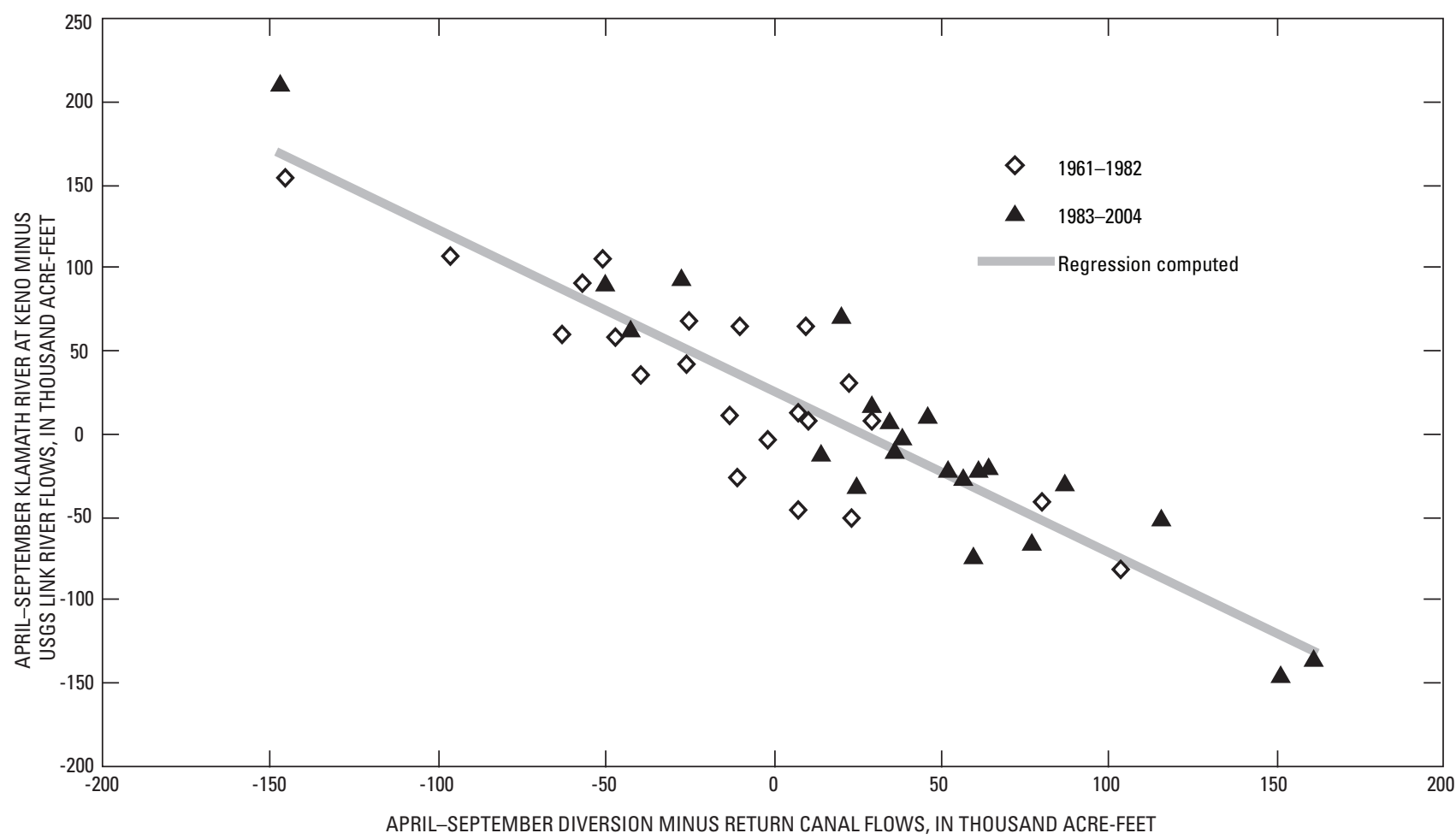

Figure 5. April-September net river and canal flows estimated using the USGS flow record for the Link River without westside power canal flow, south-central Oregon, 1961-2004.

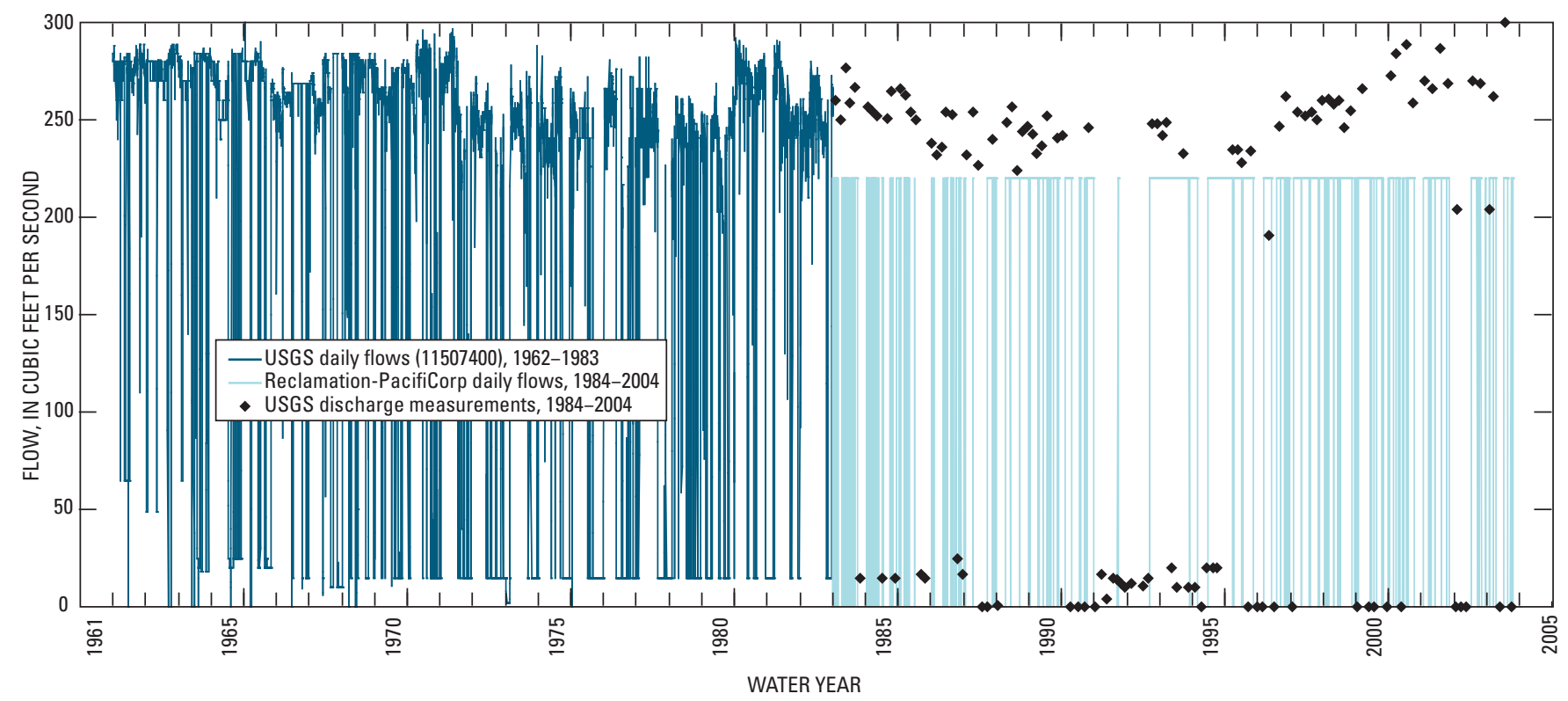

Figure 6. Comparison of U.S. Geological Survey and Bureau of Reclamation-PacifiCorp westside power canal flows, southcentral Oregon, 1961-2004. 
During the earlier period for the westside power canal (water years 1962-83), estimated daily flow was greater than $200 \mathrm{ft}^{3} / \mathrm{s}$ on an average of 252 days of the year. During the later period (water years 1984-2004), estimated daily flow was greater than $200 \mathrm{ft}^{3} / \mathrm{s}$ on an average of only 180 days of the year. The number of days of power production was about 30 percent less during the later period compared with the earlier period.

The use of different rating curves also created a significant inconsistency between the two records. The mean of the USGS westside power canal check measurements and Reclamation-PacifiCorp daily flows greater than $200 \mathrm{ft}^{3} / \mathrm{s}$ (during power production) in the later period (water years 1984-2004) was 251 and $220 \mathrm{ft}^{3} / \mathrm{s}$, respectively. Based on the annual average number of days of power production reported by PacifiCorp (180 days) during this period, approximate canal flow volume during this period would have been about 90,000 acre-ft/yr using the USGS flow rate and about 79,000 acre-ft/yr using the Reclamation-PacifiCorp flow rate. Thus, the Reclamation-PacifiCorp canal flow record for water years 1984-2004 could be 11,000 acre-ft/yr less than what it should be. During the earlier period (water years 1962-1983), the USGS westside power canal flow was about 130,000 acreft/yr. Thus, the 1984-2004 Reclamation-PacifiCorp canal flow record contains an approximate flow decrease of 51,000 acre$\mathrm{ft} / \mathrm{yr}$ between the two time periods that is attributable to both decreased power production and possible flow-measurement error. If the USGS canal flow rate is more accurate, the flow decrease (due to decreased power production) would be only 40,000 acre-ft/yr.

Possible error in the river portion of the ReclamationPacifiCorp flow record for the Link River was found when the record was compared with the USGS Link River record. A comparison of USGS and Reclamation-PacifiCorp Link River and westside power canal flow records for water years 1961-2004 is shown in table 5. As discussed earlier, the Reclamation-PacifiCorp Link River flow record was based on a different rating curve for the river than the USGS rating curve. The difference between the USGS and ReclamationPacifiCorp Link River flow records is shown in table 5, column F. For water years 1961-83, the USGS canal flow record (table 5, column D) is included in the USGS Link River flow record (table 5, column A). For water years 1984-2004, the USGS canal flow record (table 5, column D) is estimated by adding 11,000 acre-ft to the Reclamation-PacifiCorp canal flow record (table 5, column E). The estimated USGS canal flow record was then added to the USGS Link River flow record (table 5, column B) to create an estimated USGS combined Link River and canal flow record (table 5, column A).

For the first 22-year period, water years 1961-82, the river portion of the Reclamation-PacifiCorp Link River flow record probably overestimated the actual flow by 25,000 acre-ft/yr on average. For the second 22-year period, water years 1983-2004, the river portion of the ReclamationPacifiCorp Link River flow record probably underestimated flows by about 7,000 acre-ft/yr on average. The most likely source of error was bias in the rating curve used by PacifiCorp for the river gage. This combined error of 32,000 acre-ft/yr is consistent with the larger water-balance error shown in $\underline{\text { tables } 3}$ and $\underline{4}$. However, it does not explain all of the waterbalance errors.

As a result of possible errors in both the river and power canal flow data and limited documentation, the Link River Reclamation-PacifiCorp flow record was rated as "poor."

\section{Lost River Diversion Channel at Lost River Diversion Dam}

Built in 1912, the Lost River Diversion Dam was constructed to divert water from the Lost River into the constructed Lost River Diversion Channel. Flows are monitored by Reclamation with two Stevens ${ }^{\circledR}$ drum recorders mounted on stilling wells located upstream and downstream of the diversion gates. The stage difference is used to compute velocity. Flow is computed by multiplying velocity by the total gate opening area and a coefficient of discharge. Unlike the North and Ady Canal gates, there is a greater gradient at this site, and if the site had better data documentation, the flow record might have been rated as "fair." However, because of documentation deficiencies, this flow record was rated as "poor."

\section{Lost River Diversion Channel at Miller Hill Pumping Plant}

A small amount of excess water at the Miller Hill Pumping Plant that is spilled back into the Lost River Diversion Channel is included in the water-balance equation. Because the pumps are single speed, more water is sometimes pumped out of the Lost River Diversion Channel than is needed for irrigation. Spill water flows back into the channel by gravity through a gate opening. Manually measured and recorded flows are computed using a gate opening versus discharge rating table and time durations of the gate opening. Because of these factors and limited data documentation, this flow record was rated as "poor."

The Klamath Irrigation District started keeping records of the spill water return flows in water year 1987. Because the flow magnitude of this record is only 0.18 percent of all flow returns in the water balance, mean monthly flows for 19872004 were used to fill in the missing period from 1961 to 1986 for the water-balance computation. 
Table 5. Annual flow records of U.S. Geological Survey and Bureau of Reclamation-PacifiCorp Link River and westside power canal, south-central Oregon, water years 1961-2004.

[Values in thousand acre-feet. Water year: October 1 to September 30. 1984-2004: Column A for water years 1984-2004 estimated by adding Columns B and D. Column D for water years 1984-2004 estimated by adding 11 thousand acre-feet per year to Column E values. Abbreviations: USGS, U.S. Geological Survey; Reclamation, Bureau of Reclamation; PC, PacifiCorp; na, not available]

\begin{tabular}{|c|c|c|c|c|c|c|}
\hline \multirow{2}{*}{ Water year } & \multicolumn{3}{|c|}{ Link River } & \multirow{2}{*}{$\begin{array}{l}\text { USGS } \\
\text { Canal only } \\
\text { (D) }\end{array}$} & \multirow{2}{*}{$\begin{array}{l}\text { Reclamation-PC } \\
\text { Canal only } \\
\text { (E) }\end{array}$} & \multirow{2}{*}{$\begin{array}{c}\text { Error: } \\
\text { Columns A } \\
\text { minus C } \\
\text { (F) }\end{array}$} \\
\hline & $\begin{array}{c}\text { With canal } \\
\text { (A) }\end{array}$ & $\begin{array}{l}\text { Without canal } \\
\text { (B) }\end{array}$ & $\begin{array}{c}\text { Reclamation-PC } \\
\text { With canal } \\
\text { (C) }\end{array}$ & & & \\
\hline \multicolumn{7}{|c|}{ 1961-83 } \\
\hline 1963 & 1,166 & 973 & 1,207 & 193 & na & -41 \\
\hline 1964 & 878 & 714 & 930 & 164 & na & -53 \\
\hline 1965 & 1,695 & 1,549 & 1,794 & 145 & na & -99 \\
\hline 1966 & 1,029 & 877 & 1,049 & 152 & na & -20 \\
\hline 1967 & 1,077 & 903 & 1,115 & 174 & na & -38 \\
\hline 1968 & 785 & 637 & 805 & 147 & na & -21 \\
\hline 1972 & 1,567 & 1,425 & 1,551 & 141 & na & 16 \\
\hline 1973 & 982 & 868 & 1,049 & 115 & na & -67 \\
\hline 1974 & 1,501 & 1,387 & 1,545 & 113 & na & -44 \\
\hline 1975 & 1,319 & 1,185 & 1,338 & 134 & na & -19 \\
\hline 1976 & 1,115 & 1,010 & 1,122 & 104 & na & -7 \\
\hline 1977 & 709 & 601 & 738 & 107 & na & -29 \\
\hline 1978 & 1,175 & 1,057 & 1,210 & 117 & na & -35 \\
\hline 1979 & 804 & 681 & 838 & 123 & na & -35 \\
\hline 1980 & 797 & 676 & 826 & 120 & na & -29 \\
\hline 1981 & 735 & 566 & 712 & 169 & na & 22 \\
\hline 1982 & 1,403 & 1,267 & 1,419 & 136 & na & -17 \\
\hline 1983 & 1,683 & 1,529 & 1,684 & 154 & na & -1 \\
\hline \multicolumn{7}{|c|}{ 1984-2004 } \\
\hline 1989 & 1,013 & 895 & 1,021 & 118 & 107 & -8 \\
\hline 1990 & 673 & 546 & 681 & 127 & 116 & -8 \\
\hline 1991 & 519 & 426 & 529 & 93 & 82 & -11 \\
\hline 1992 & 413 & 397 & 396 & 16 & 5 & 18 \\
\hline 1993 & 1,037 & 972 & 1,025 & 65 & 54 & 12 \\
\hline 1994 & 669 & 499 & 589 & 170 & 159 & 80 \\
\hline 1995 & 846 & 729 & 797 & 117 & 106 & 49 \\
\hline 1996 & 1,451 & 1,312 & 1,427 & 140 & 129 & 25 \\
\hline 1997 & 1,363 & 1,268 & 1,379 & 95 & 84 & -16 \\
\hline 1998 & 1,412 & 1,270 & 1,385 & 141 & 130 & 27 \\
\hline 1999 & 1,449 & 1,310 & 1,407 & 138 & 127 & 42 \\
\hline 2000 & 1,148 & 1,035 & 1,098 & 113 & 102 & 50 \\
\hline 2001 & 757 & 669 & 716 & 87 & 76 & 41 \\
\hline 2002 & 778 & 661 & 728 & 117 & 106 & 50 \\
\hline 2003 & 705 & 652 & 665 & 53 & 42 & 39 \\
\hline 2004 & 696 & 629 & 653 & 67 & 56 & 43 \\
\hline
\end{tabular}




\section{Klamath Straits Drain at F-FF Pumping Plant}

The F-FF Pumping Plant is located near the intersection of the Klamath Straits Drain and U.S. Highway 97. The Straits Drain is the primary flow conduit for return water from the Klamath Project and the Lower Klamath and Tule Lake National Wildlife Refuges. This site includes two pumping plants ( $\mathrm{F}$ and $\mathrm{FF}$ ) and is operated by Reclamation and the Klamath Drainage District. Plants F and FF were constructed in 1941 and 1980, respectively.

Over the past 60 years, two methods of flow computation have been used to create the flow record at this site. One method uses the stage difference between the outlet and sump (upstream and downstream) and a stage-discharge relation curve. The other method uses the manufacturer's original pump capacity curves.

The first method probably was used to compute the flow record for much of the 1940s and 1950s. Reclamation made a series of discharge measurements to develop a stage-discharge relation for Plant F, which appeared relatively accurate.

However, in more recent years the flow record appears to have been computed entirely on the manufacturer's pump capacity curves. On the basis of those curves, the combined maximum flow capacity of the plants theoretically is $600 \mathrm{ft}^{3} / \mathrm{s}$. However, there is no evidence that any of the pump capacity curves were recently compared with the field-developed capacity curves. There is no documentation of check measurements on any of the pumps since the 1960s. Severe cavitation occurred about 5 years ago at one of the pumps, which has rendered it less efficient (Al Wilder, Bureau of Reclamation, Klamath Falls, Oregon, oral commun., 2005). Because of these factors and limited data documentation, this flow record was rated as "poor."

\section{Non-Water-Balance Flow Data}

Numerous smaller return and diversion flows enter or leave the Klamath River between the Link River at Klamath Falls and the Klamath River at Keno. These additional flows were not included in the water-balance equation because they were measured on an irregular basis, poorly documented, and/or considered insignificant in magnitude. Nonetheless, it was necessary to determine if changes in these flows over time could have had a significant effect on the water balance and been a factor in the flow inconsistency. A summary of the return and diversion flows is shown in table 6. Table 6 includes circa 2004 flow estimates in addition to how these estimates compare with probable flow conditions in the 1960s.

\section{Diversion Flows from the Klamath River}

Most of the unmeasured or poorly measured diversions have been used for irrigated agriculture and the wood products industry. Historical water right permits granted by the Oregon Water Resources Department (OWRD) provide some insight into the magnitude of the diversions, although it cannot be assumed that a water user will use the full amount of water that they are allowed to use. In some years, a water right holder may not use the appropriated water at all. The water rights granted by OWRD in the water budget reach provided an estimate of the maximum potential uses in addition to the measured Klamath Project diversions and returns. An increase in undocumented surface-water diversions from the Klamath River would be inconsistent with changes in the water balance over the 44-year period from 1961 to 2004.

\section{Agriculture}

Some landowners adjacent to the Klamath River have surface-water withdrawal permits for agricultural use. Between the Link River and Keno Dams, the sum of these numerous small diversions has been estimated to be about 25,000 acre$\mathrm{ft} / \mathrm{yr}$ (PacifiCorp, 2005). Although this amount is significant, there is no available quantitative or anecdotal evidence of changes in irrigation practices over the 44-year study period that would explain the water-balance inconsistencies. Few new water rights have been granted to landowners on this stretch of the Klamath River since 1971. At the same time, these direct diversions for irrigated agriculture adjacent to the river have not likely decreased by a significant amount.

Table 6. Diversion and return flows not used in water-balance calculations for the reach of the Klamath River, south-central Oregon.

[Flows are given in thousand acre-feet per year. Abbreviations: WWTP, wastewater-treatment plant; SSS, South Surburban Sanitation]

\begin{tabular}{|c|c|c|c|c|}
\hline \multirow{2}{*}{ Water use } & \multicolumn{2}{|c|}{ Diversion flow } & \multicolumn{2}{|c|}{ Return flow } \\
\hline & Current & $1960 \mathrm{~s}$ & Current & $1960 \mathrm{~s}$ \\
\hline $\begin{array}{l}\text { Klamath Falls WWTP } \\
\text { effluent }\end{array}$ & None & None & 12.00 & 2.50 \\
\hline SSS WWTP effluent & None & None & 7.60 & Less \\
\hline Other storm runoff & None & None & ${ }^{2} 4.00$ & Less \\
\hline Lumber mills & ${ }^{3} 0$ to 1.6 & Same & 0.90 & More \\
\hline Irrigated agriculture & ${ }^{2} 25.00$ & Same & ${ }^{4} 6.25$ & More \\
\hline Total & 25.00 & Same & 19.75 & Less \\
\hline
\end{tabular}

${ }^{1}$ Includes Klamath Falls Cogeneration Power Project plant evaporation losses.

${ }^{2}$ Estimates from PacifiCorp (2005).

${ }^{3}$ Lumber mills have combined water rights to 1.6 thousand acre-feet per year. Most of these rights are kept for fire suppression and the water is rarely diverted from the river.

${ }^{4}$ Return flows were assumed to be 25 percent of irrigated diversions. 


\section{Wood Products}

Some other water users in the study area include wood-products processing plants. In the 1960s, four major plants existed, which included Modoc Lumber, D.G. Shelter Products, Collins Products LLC (formerly Weyerhaeuser), and Columbia Plywood. As of water year 2004, only Columbia Plywood and Collins Products LLC existed. Historically, water has been used at these facilities for the manufacturing and processing of plywood, cardboard, and wood siding products, and for log sprinkling to reduce the potential for fire. However, the Collin Products LLC plant stopped using logs altogether in 1992 and now relies on wood chips. Columbia Plywood still uses logs; however, their logs are stored in the river and do not need to be kept wet using sprinklers (Ted Devore, Collins Products LLC, Klamath Falls, Oregon, oral commun., 2005).

A query of the OWRD water rights information data base found the combined total surface-water rights permits for the four plants to be about 1,600 acre-ft/yr. Historically, however, most of the water used by the plants has come from groundwater wells. The two remaining plants take very little water directly out of the river. The surface-water right permits are kept mostly for fire suppression (Ted Devore, Collins Products LLC, Klamath Falls, Oregon, oral commun., 2005).

Although difficult to quantify, overall water diversions for the wood products industry in the study area likely has decreased between 1961 and 2004, mainly because there are fewer plants in operation. A trend of less water diversion is consistent with the water-balance inconsistency; however, an amount of only 1,600 acre-ft/yr is too small to explain it.

\section{Return Flows to the Klamath River}

Return flows to the Klamath River that are not included in the water-balance equation include outflows from wastewater-treatment and wood-products processing plants. An increase in undocumented surface-water return flows to the Klamath River would be consistent with changes in the water balance over the 44-year period from 1961 to 2004.

\section{Agriculture}

Return flows from irrigated agriculture on lands adjacent to the Klamath River were not measured. However, 25 to 50 percent of irrigation diversion flows is considered a reasonable estimate for return flows in the Upper Klamath Basin (Broad and Collins, 1996). Using a rate of 25 percent, return flows for water year 2004 were estimated at 6,250 acre-ft/yr. Return flows in the 1960s possibly were higher than in water year 2004 because of more flood irrigation and less sprinkler irrigation at that time. For many locations in the upper Klamath Basin, the transition from flood irrigation to sprinkler irrigation has reduced return flows (Burt and Freeman, 2003).

\section{Wastewater Treatment}

The study area is served by two main wastewatertreatment plants (WWTP). One is operated by the City of Klamath Falls and the other by the South Suburban Sanitation District. As a result of population growth, these flows have gradually increased. Between 1960 and 2000, the population of Klamath County increased from 47,475 to 63,775 (U.S. Census Bureau, 2005). Annual average effluent releases from the Klamath Falls WWTP have increased at a steady rate from about $2.2 \mathrm{Mgal} / \mathrm{d}(2,464 \mathrm{acre}-\mathrm{ft} / \mathrm{yr})$ in the early $1960 \mathrm{~s}$ to about $3.0 \mathrm{Mgal} / \mathrm{d}$ (3,360 acre-ft/yr) in water year 2004 . The Klamath Falls WWTP also currently (water year 2004) treats about 0.22 to $0.3 \mathrm{Mgal} / \mathrm{d}$ of urban storm and geothermal runoff, which when combined with effluent outflow is about 3.3 Mgal/d (3,696 acre-ft/yr) (Jeff Fritz, City of Klamath Falls, Oregon, oral commun., 2005). On an annual basis, this increase in quantity is insufficient to explain the waterbalance inconsistency. Not all WWTP outflow is discharged to the Klamath River. Since 2001, the Klamath Cogeneration Project Power Plant has been using about two-thirds of the WWTP outflow for cooling purposes. About one-third of that amount (less than 1,000 acre-ft/yr), the portion that is not evaporated, is returned to the WWTP and then discharged to the Klamath River (Jeff Fritz, City of Klamath Falls, Oregon, oral commun., 2005). Total effluent discharged to the river is approximately 2,000 acre-ft/yr.

From the early 1990 s to the mid-2000s, an annual average of about $2.5 \mathrm{Mgal} / \mathrm{d}(2,820 \mathrm{acre}-\mathrm{ft} / \mathrm{yr})$ of effluent was treated by the South Suburban Sanitation District WWTP. This rate is about three times what it was in 1961. In 2004, the total combined sewer outflow from this plant (which includes effluent, storm runoff from streets, and geothermal return flows) was about $6.8 \mathrm{Mgal} / \mathrm{d}$ (7,600 acre-ft/yr) (Sally Braton, South Suburban Sanitation District, Klamath Falls, Oregon, oral commun., 2005). PacifiCorp (2005) estimated an additional 4,000 acre-ft/yr of storm runoff from other locations in the study reach. Although flows are higher than in the early 1960s, the amount of increase is insufficient to explain the water-balance inconsistency.

\section{Wood Products}

The two remaining wood-products processing plants in the study area, Collins Products LLC and Columbia Plywood, discharge an average of 900 and 30 acre-ft/yr, respectively (Burt and Freeman, 2003). In the 1960s, when there were additional wood-products processing plants in operation, the total return flows would have been greater than the current total flows of 903 acre-ft/yr. However, a decrease in return flows from these plants would have been contrary to the trend in the water balance, in addition to being insignificant. 


\section{Ground-Water Levels and Climate}

Changing ground-water levels in land adjacent to the river between the Link River and Keno Dams also could cause a water-balance inconsistency. Because the water balance shows a losing stream in the 1960s and 1970s and a gaining stream in the 1980s and 1990s, ground-water levels would have had to rise during the 44-year period; however, water-level data collected by the OWRD and the USGS from wells in or near the study reach do not show a rising ground-water-level trend (http://or.water.usgs.gov/projs dir/or180/waterlevels/index. html, accessed March 29, 2006).

The nearest long-term OWRD observation wells to the study area include KLAM 11950 and KLAM 12815. The record for KLAM 11950, a geothermal well located within the city limits of Klamath Falls, began in the late 1960s. From that time to the present, this record does not show an overall increase in water levels. The water level in KLAM 11950 declined by $15 \mathrm{ft}$ between 1975 and 1990, followed by a recovery between 1990 and 1995. The observed decline was likely due to a combination of development of the geothermal aquifer and climate influences. The recovery of the water table is undoubtedly due to an increase in the practice of injecting spent geothermal water back into the aquifer that was mandated after July 1990 by city ordinance. As far as is known, this decline and recovery is limited to the geothermal aquifer in and around Klamath Falls. According to Sammuel (1980) the total discharge of the geothermal system in and around Klamath Falls is 2,868,000 gallons per day, or about 3,200 acre-ft/yr. On the basis of that volume, pumping and injection practices in the geothermal aquifer are unlikely to have a measurable effect on flow in the Klamath River. (Marshall Gannett, USGS, Portland, Oregon, oral commun., 2006). The record for KLAM 12815, located about 4 mi east of the river, shows an overall decline in water levels of about 8 ft between the early 1960s and the early 1990s. This decline, which is likely climatological in origin, is contrary to the water-balance inconsistency.

Closer to the river, below Klamath Falls and above the Keno flow-measurement site, the USGS has collected waterlevel data from seven observation wells (KLAM 10013, KLAM 10253, KLAM 11211, KLAM 13744, KLAM 13800, KLAM 50392, and KLAM 51231) since 1999 for the USGS upper Klamath Basin ground-water study. Because of drier than average conditions for most of the period since 1999, water levels generally declined in all seven wells. Although the period of record for these wells does not represent the longer period from 1961 to 2004, additional water-level measurements made at the time the wells were drilled are available. KLAM 13800 and KLAM 13744 were drilled in 1974 and 1988, respectively, and the other wells were drilled during the 1990s. The water levels in all seven wells at the time they were drilled are within the range of their measured water-levels over the past 7 years. Therefore, the possibility that there has been an overall rise in water levels over the period from 1961-2004 is not supported by the OWRD and USGS water-level data.

Precipitation data (fig. 7) also do not support a rise in ground-water levels. A long-term shift from drier to wetter weather would cause such a change, but although there are periods of wet and dry years, long-term precipitation did not significantly increase. Mean annual water year precipitation at Klamath Falls for 1961-82 and 1983-2004 was 13.3 and 13.8 in., respectively, which is a difference of less than 5 percent. Precipitation at other nearby sites also did not differ significantly between the two 22-year periods. Mean annual precipitation at Crater Lake for water years 1961-82 and 1983-2004 was 65.8 and 64.63 in., respectively.

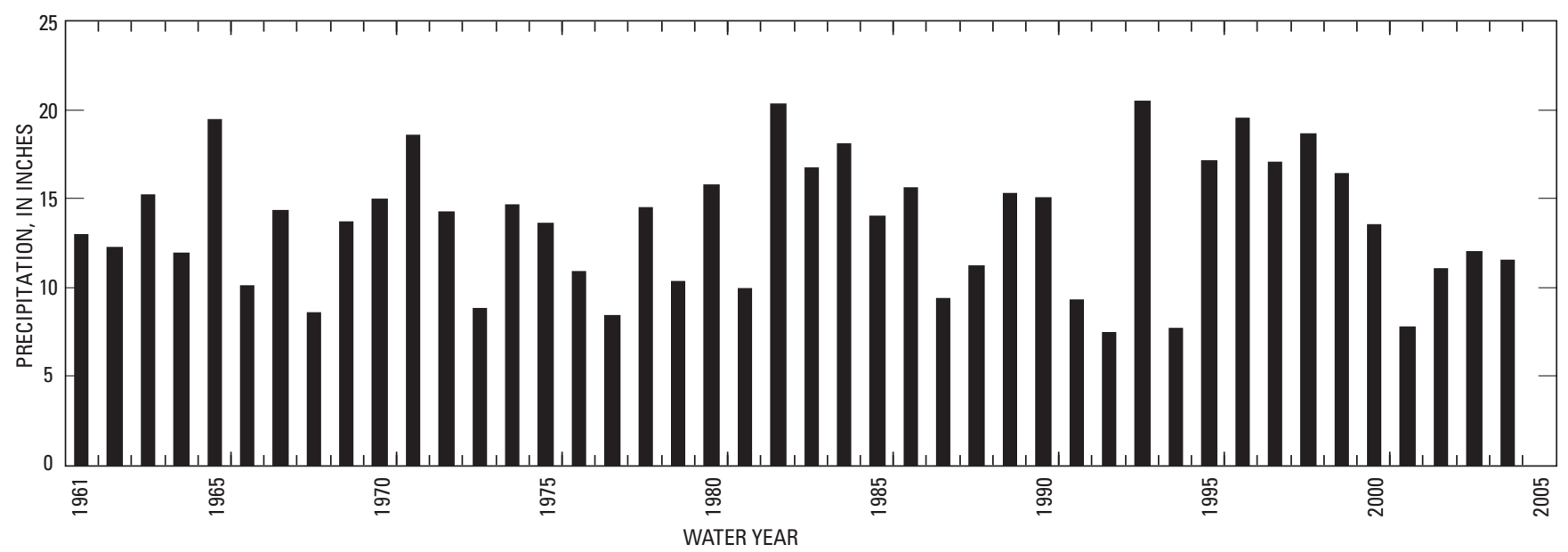

Figure 7. Precipitation for Klamath Falls, south-central Oregon, water years 1961-2004. 


\section{Time-Series Trend Analysis}

Trends in the four canal diversions (fig. 8A-D), the three canal returns (fig. 9A-C), and flow records for the Link River were visually evaluated to gain insights into watermanagement changes related to the Klamath Project and the National Wildlife Refuges over the 44-year period. Trends in these eight flow records cannot be used to explain the waterbalance inconsistency because these same trends would be inherent in the downstream flow record (Klamath River at Keno), which also was used in the water-balance calculations and is assumed to be accurate. Nonetheless, the analysis of trends was included to determine whether known watermanagement changes are evident in the flow data. Also, the extent of possible error in the flow records could be assessed by noting how consistent or inconsistent the records were with each other.

\section{Canal Diversion Flows}

With the exception of the Miller Hill Pumping Plant diversion on the Lost River Diversion Channel (fig. 8B), the records for the three other canal diversions show flow increases over time (figs. $8 A, \underline{8 C}$, and $\underline{8 D}$ ). The changes in flow rate can also be seen in a cumulative line plot of each of the canal diversions (fig. 10). The solid lines show cumulative measured flows. A change in the slope of these lines represents a change in the flow rate. The straight dotted trend lines show what the cumulative line plots would have looked like if there were no changes in the flow rate over time. By plotting the differences between the cumulative line plots and the trend lines (cumulative residuals) from figure 10, it is possible to more easily see changes, or breaks, in flow rates (fig. 11). Flow rates for both North and Ady Canals increased around 1984 and 1985. Flow rates for Station 48 increased around 1978 and again around 1991. Also, flow-rate changes for Station 48 and Ady Canal were greater and more abrupt than flow-rate changes for the North Canal. For Station 48, North Canal, and Ady Canal flow records, 1983-2004 mean annual diversion flows were about 16,000, 8,000, and 21,000 acre-ft/yr greater than their 1961-82 mean annual diversion flows (table 7).

The increase in diversion flows possibly can be explained by known water-management changes that occurred over the 44-year period. By the 1980s, many farms in the Klamath
Project had converted from flood to sprinkler irrigation. If managed correctly, sprinkler irrigation can conserve water better than flood irrigation. However, total annual water use can increase when sprinkler irrigation is introduced because higher market value row crops (such as onions, potatoes, strawberries, and peppermint) that require more water are grown instead of nonrow crops (such as winter grain and annual hay) that require less water and were grown under flood irrigation. Conversion to sprinkler irrigation often changes overall farm management. Smaller, but more numerous, irrigation applications are applied to the crops. Applications are also made for frost control and preseason field preparation that would not have been made using flood irrigation (Mike Green, Bureau of Reclamation, Klamath Falls, Oregon, oral commun., 2005).

Diversions at Station 48 increased significantly in the 1990s (figs. 8A and 11) for two possible reasons. One could be related to increased sprinkler irrigation and increased row crop production in the Tulelake Irrigation District (Jerry Pyle, Tulelake Irrigation District, Tulelake, California, oral commun., 2005). More water was also needed for the Tule Lake Refuge. Flows from the Station 48 diversion flow to the refuge through the Lost River. As a result of an Endangered Species Act requirement, minimum water levels in Sump 1A and 1B were raised by $0.5 \mathrm{ft}$ beginning in 1992 (Mike Green, Bureau of Reclamation, Klamath Falls, Oregon, oral commun., 2005).

The North and Ady Canals provide water to the KDD lands and the Lower Klamath Wildlife District. Flow diversions used for both winter (for mostly grain) and summer irrigation are shown in figures $8 C$ and $8 D$. In the 1980s and 1990s, summer irrigation was higher than in the 1960s and 1970s. Some of the increased summer irrigation is likely a consequence of increased sprinkler irrigation and row crop production in farmlands served by these two canals (Mike Green, Bureau of Reclamation, Klamath Falls, Oregon, oral commun., 2005).

Not all increased flows in Ady Canal at U.S. Highway 97 were diverted to irrigation use. Ady Canal also provides water to the Lower Klamath Refuge. The flow record for the Ady Canal site located at Stateline Road (just upstream of the refuge) indicates that more autumn, winter, and spring water deliveries to the Lower Klamath Refuge in the 1990s than in earlier periods (fig. 12). These increased flows can also be seen in the Ady Canal at U.S. Highway 97 flow record (fig. $8 D$ ). 


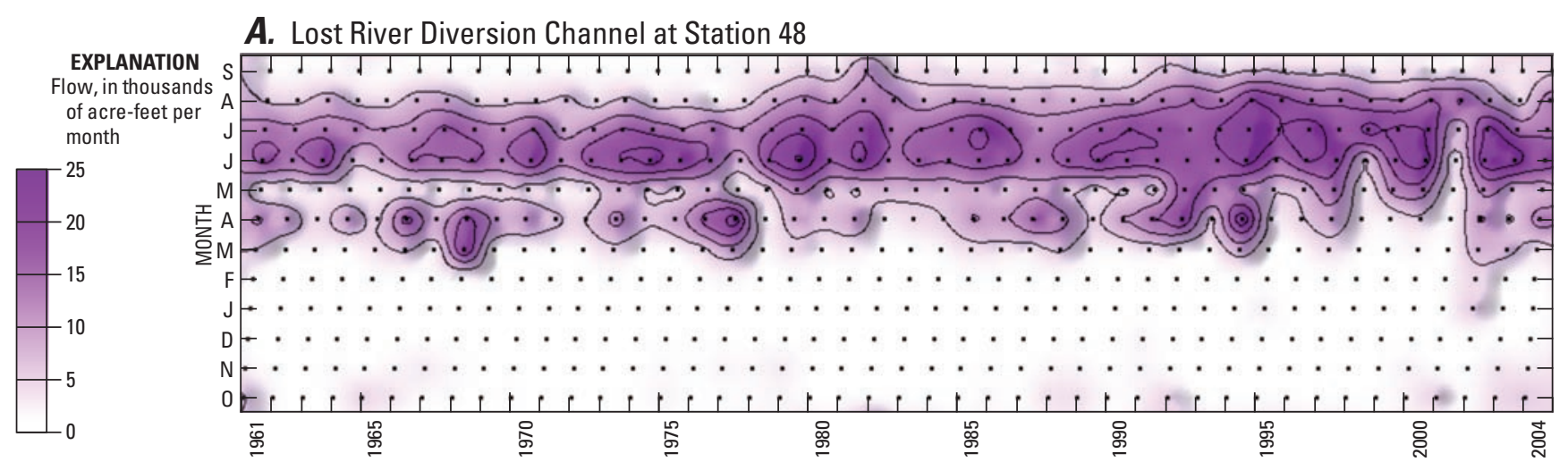

B. Lost River Diversion Channel at Miller Hill Pumping Plant

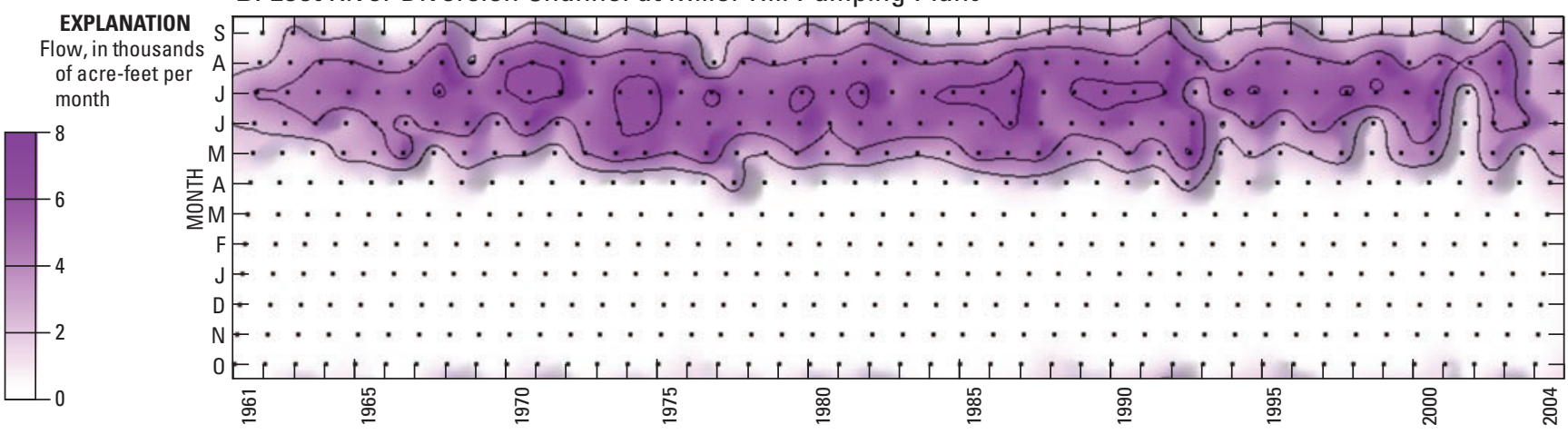

C. North Canal at U.S. Highway 97

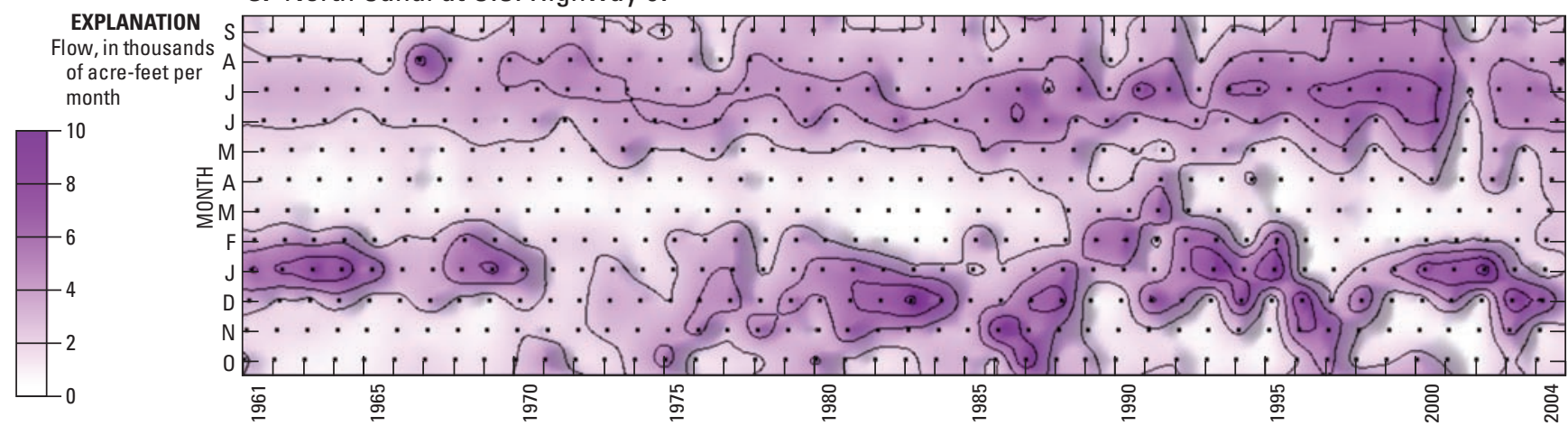

D. Ady Canal at U.S. Highway 97.

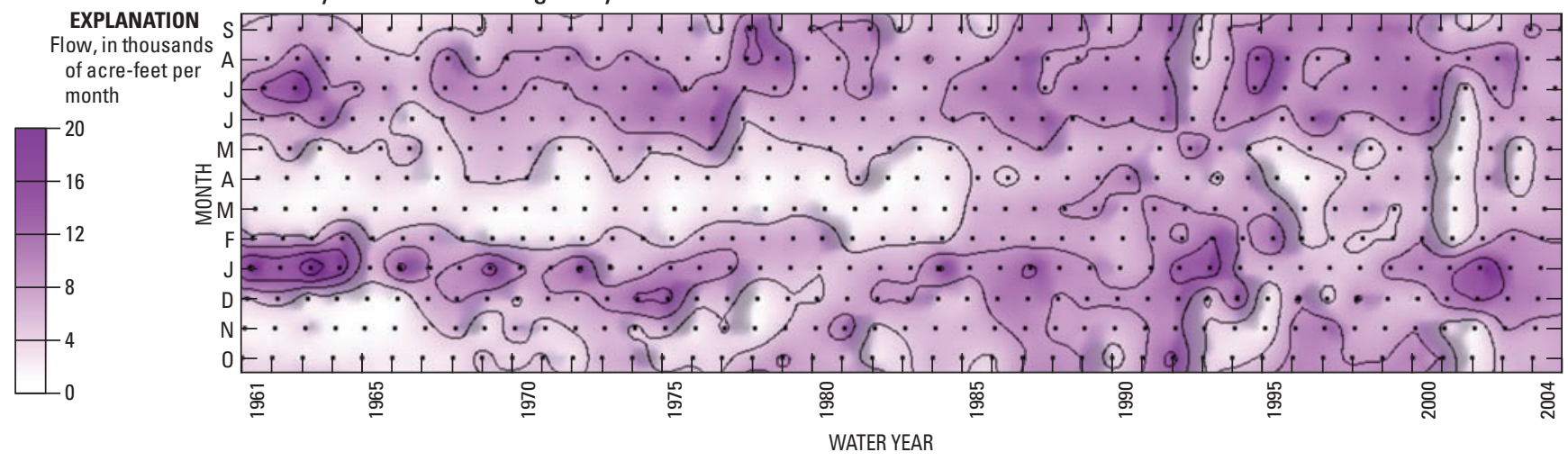

Figure 8. Monthly flows in four diversion canals, south-central Oregon, water years 1961-2004. 
A. Lost River Diversion Channel at Lost River Diversion Dam

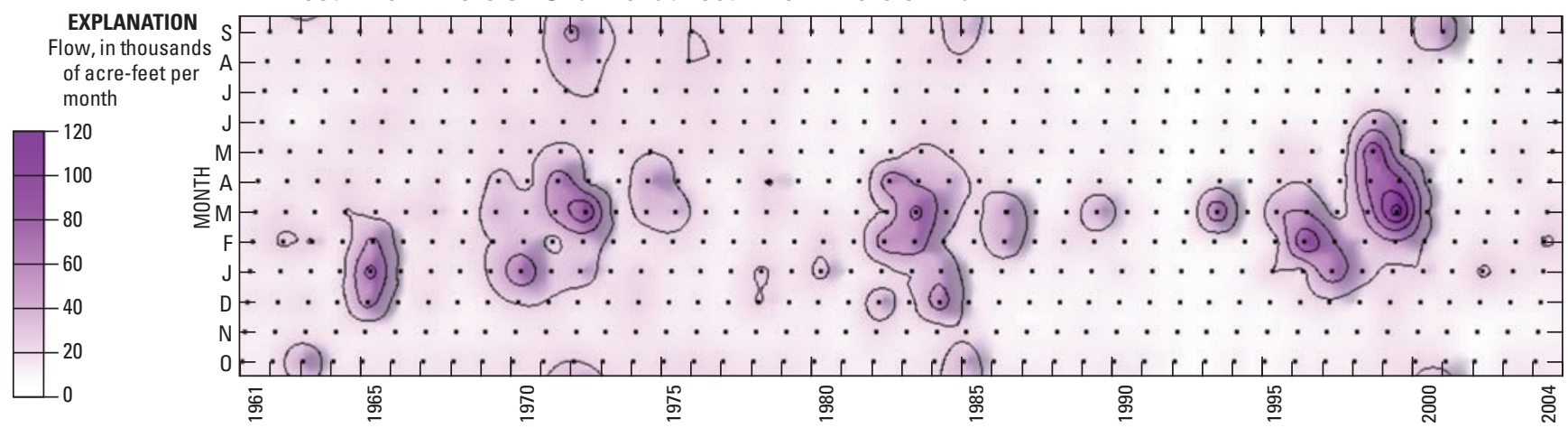

B. Lost River Diversion Channel at Miller Hill Pumping Plant

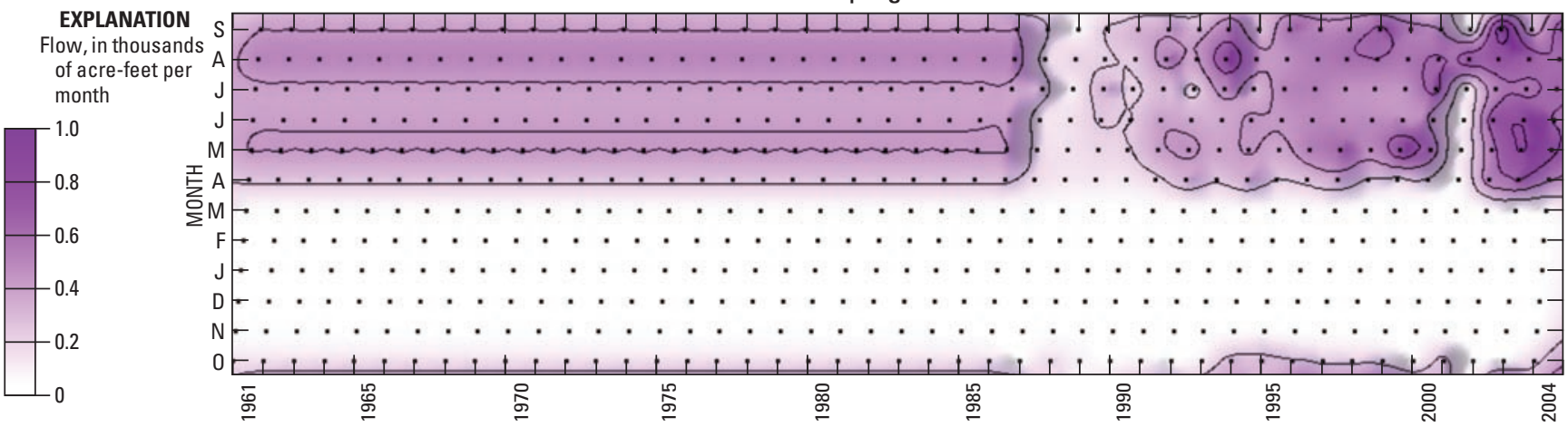

C. Klamath Straits Drain at F-FF Pumping Plant

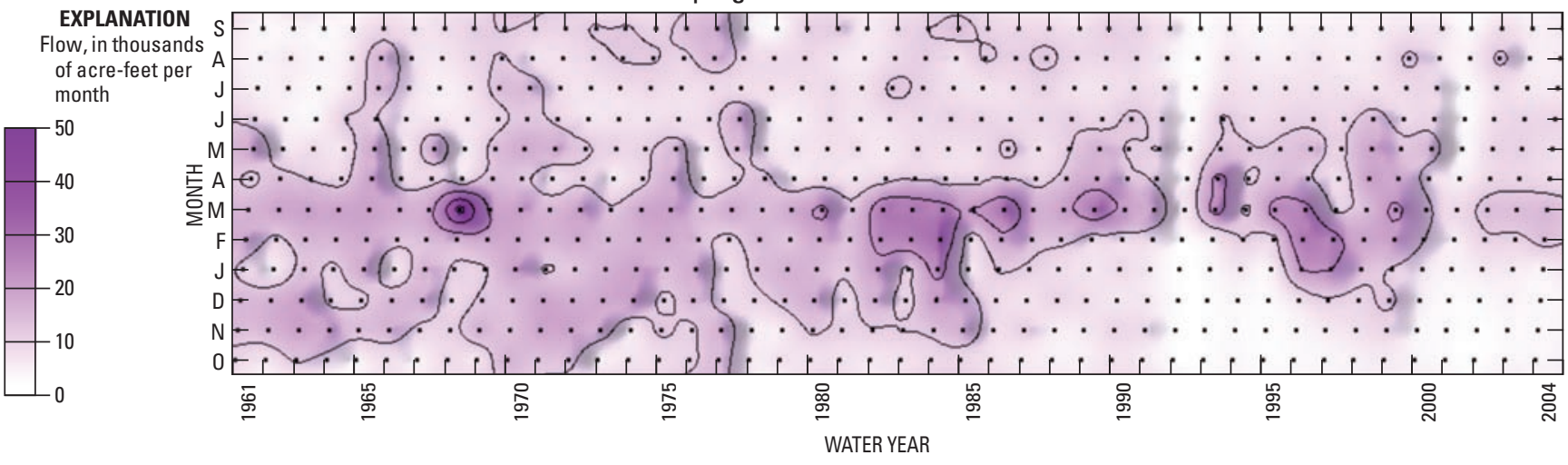

Figure 9. Monthly flows in three return-flow canals, south-central Oregon, water years 1961-2004. 


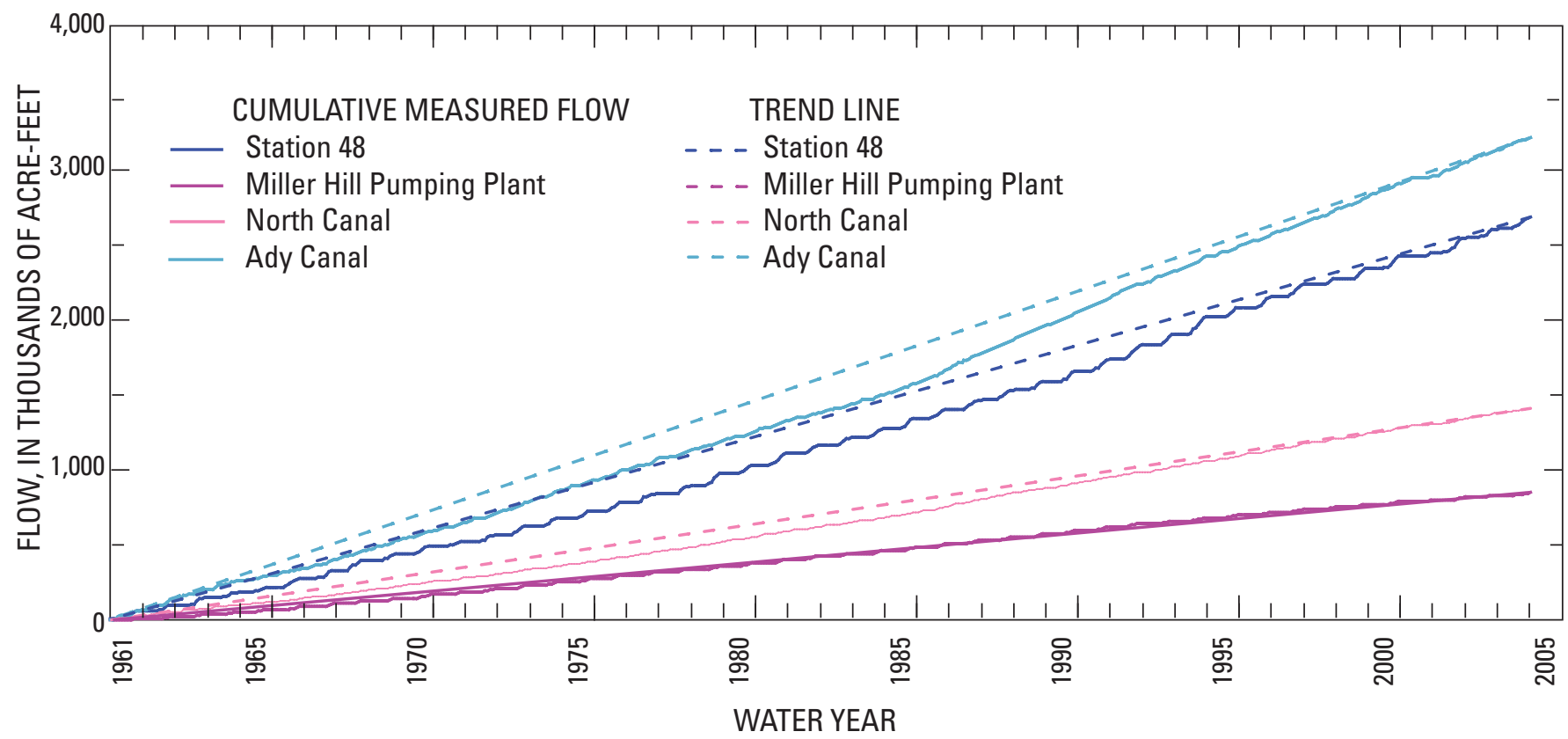

Figure 10. Cumulative monthly canal diversion flows for the water-balance reach of the Klamath River, south-central Oregon, water years 1961-2004.

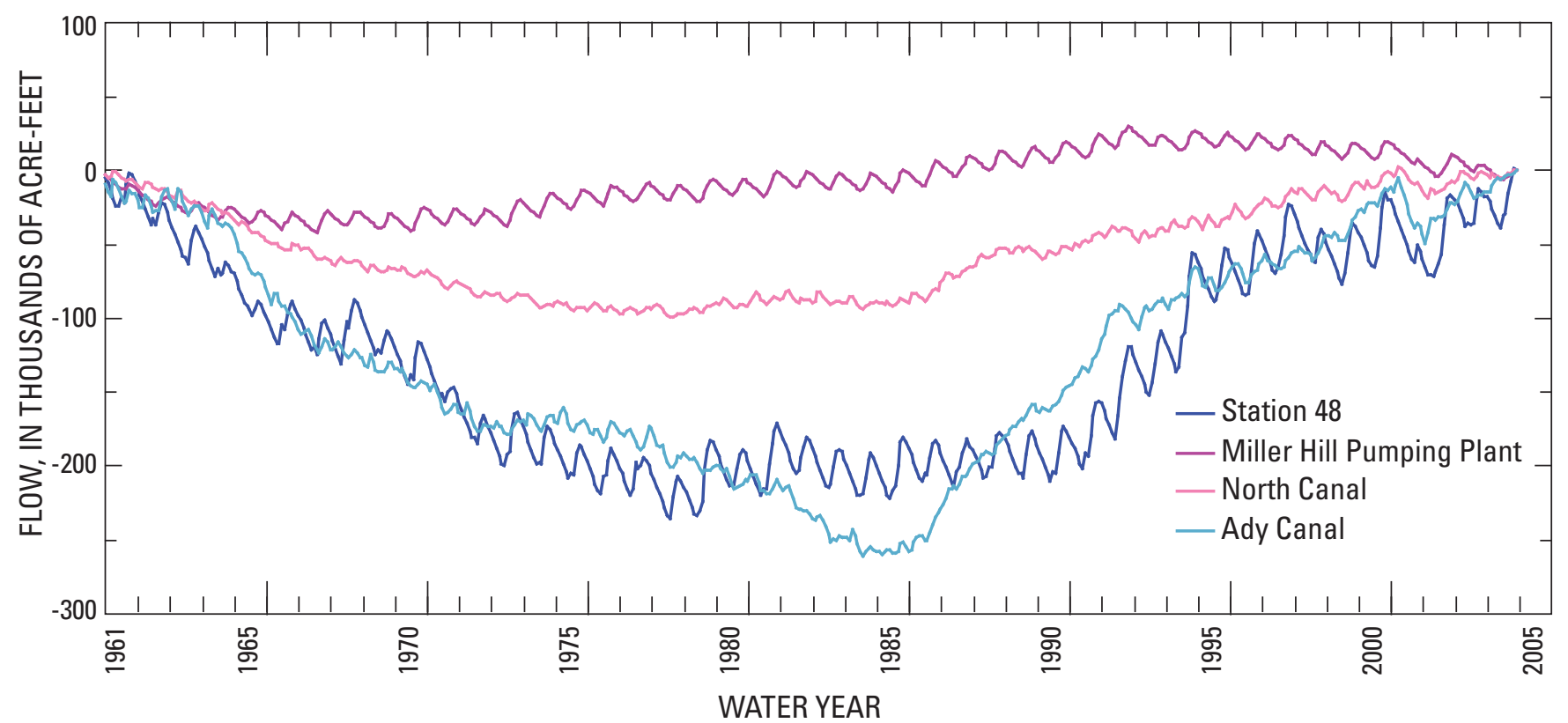

Figure 11. Cumulative residual monthly canal diversion flows for the water-balance reach of the Klamath River, southcentral Oregon, water years 1961-2004. 


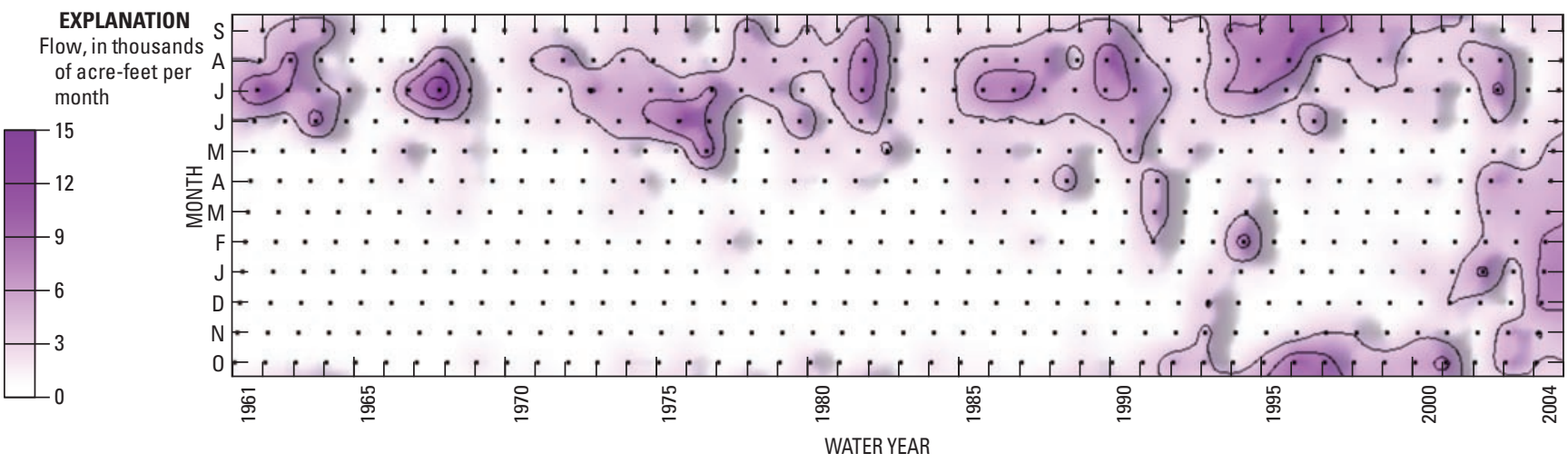

Figure 12. Monthly flow for Ady Canal at Stateline Road, south-central Oregon, water years 1961-2004.

Table 7. Mean monthly and mean annual diversion flows for the water-balance reach of the Klamath River, south-central Oregon, water years 1961-82 and 1983-2004.

[Values in thousand acre-feet; difference computed as the 1983-2004 period minus the 1961-82 period]

\begin{tabular}{|c|c|c|c|c|c|c|}
\hline \multirow[t]{2}{*}{ Month } & \multicolumn{3}{|c|}{$\begin{array}{l}\text { Lost River Diversion Channel } \\
\text { Station } 48\end{array}$} & \multicolumn{3}{|c|}{$\begin{array}{l}\text { Lost River Diversion Channel } \\
\text { Miller Hill Pumping Plant }\end{array}$} \\
\hline & 1961-82 & 1983-2004 & Difference & 1961-82 & 1983-2004 & Difference \\
\hline October & 0.85 & 1.28 & 0.43 & 0.08 & 0.18 & 0.09 \\
\hline November & .46 & .41 & -.05 & .00 & .00 & .00 \\
\hline December & .01 & .05 & .04 & .00 & .00 & .00 \\
\hline January & .00 & .31 & .31 & .00 & .00 & .00 \\
\hline February & .05 & .18 & .13 & .00 & .00 & .00 \\
\hline March & 2.82 & 2.34 & -.48 & .00 & .00 & .00 \\
\hline April & 9.30 & 8.54 & -.76 & .24 & .55 & .31 \\
\hline May & 2.97 & 7.34 & 4.37 & 2.98 & 2.96 & -.02 \\
\hline June & 16.38 & 17.52 & 1.14 & 4.53 & 4.04 & -.49 \\
\hline July & 13.14 & 17.47 & 4.33 & 5.46 & 5.22 & -.25 \\
\hline August & 5.58 & 11.09 & 5.52 & 4.18 & 4.53 & .35 \\
\hline September & 1.29 & 2.70 & 1.41 & 1.75 & 1.82 & .06 \\
\hline Annual & 52.85 & 69.22 & 16.37 & 19.23 & 19.28 & 0.05 \\
\hline \multirow[t]{2}{*}{ Month } & \multicolumn{3}{|c|}{$\begin{array}{c}\text { North Canal } \\
\text { U.S. Highway } 97\end{array}$} & \multicolumn{3}{|c|}{$\begin{array}{c}\text { Ady Canal } \\
\text { U.S. Highway } 97\end{array}$} \\
\hline & 1961-82 & 1983-2004 & Difference & 1961-82 & 1983-2004 & Difference \\
\hline October & 1.76 & 2.03 & 0.27 & 3.44 & 6.26 & 2.82 \\
\hline November & 2.19 & 2.39 & .20 & 3.28 & 6.11 & 2.83 \\
\hline December & 2.89 & 4.10 & 1.21 & 5.41 & 7.84 & 2.43 \\
\hline January & 4.21 & 3.99 & -.22 & 9.55 & 9.27 & -.27 \\
\hline February & 2.19 & 2.16 & -.03 & 4.48 & 6.15 & 1.67 \\
\hline March & .61 & 1.28 & .67 & 1.12 & 5.66 & 4.54 \\
\hline April & .73 & 1.59 & .86 & 2.13 & 4.41 & 2.28 \\
\hline May & 1.65 & 2.50 & .86 & 4.28 & 4.79 & .52 \\
\hline June & 3.11 & 4.35 & 1.24 & 6.98 & 8.29 & 1.30 \\
\hline July & 3.70 & 5.17 & 1.47 & 8.96 & 8.83 & -.13 \\
\hline August & 3.19 & 3.63 & .45 & 7.33 & 8.46 & 1.13 \\
\hline September & 1.94 & 2.84 & .90 & 5.76 & 7.52 & 1.76 \\
\hline Annual & 28.17 & 36.04 & 7.87 & 62.72 & 83.60 & 20.88 \\
\hline
\end{tabular}




\section{An Assessment of Flow Data from Klamath River Sites Between Link River Dam and Keno Dam, South-Central Oregon}

\section{Canal Return Flows}

The most significant canal return flows in the water balance are the Lost River Diversion Channel at the Lost River Diversion Dam and Klamath Straits Drain at the F-FF Pumping Plant (figs. $9 A$ and $\underline{9 C}$ ). Return flow to the Lost
River Diversion Channel at the Miller Hill Pumping Plant is insignificant by comparison (fig. 9 B $)$. Cumulative line and cumulative residual plots of the canal return flows are shown in figures 13 and $\underline{14}$, respectively. The Lost River Diversion Dam and, to a lesser extent, the F-FF Pumping Plant plots, show some correspondence to historical wet and dry periods

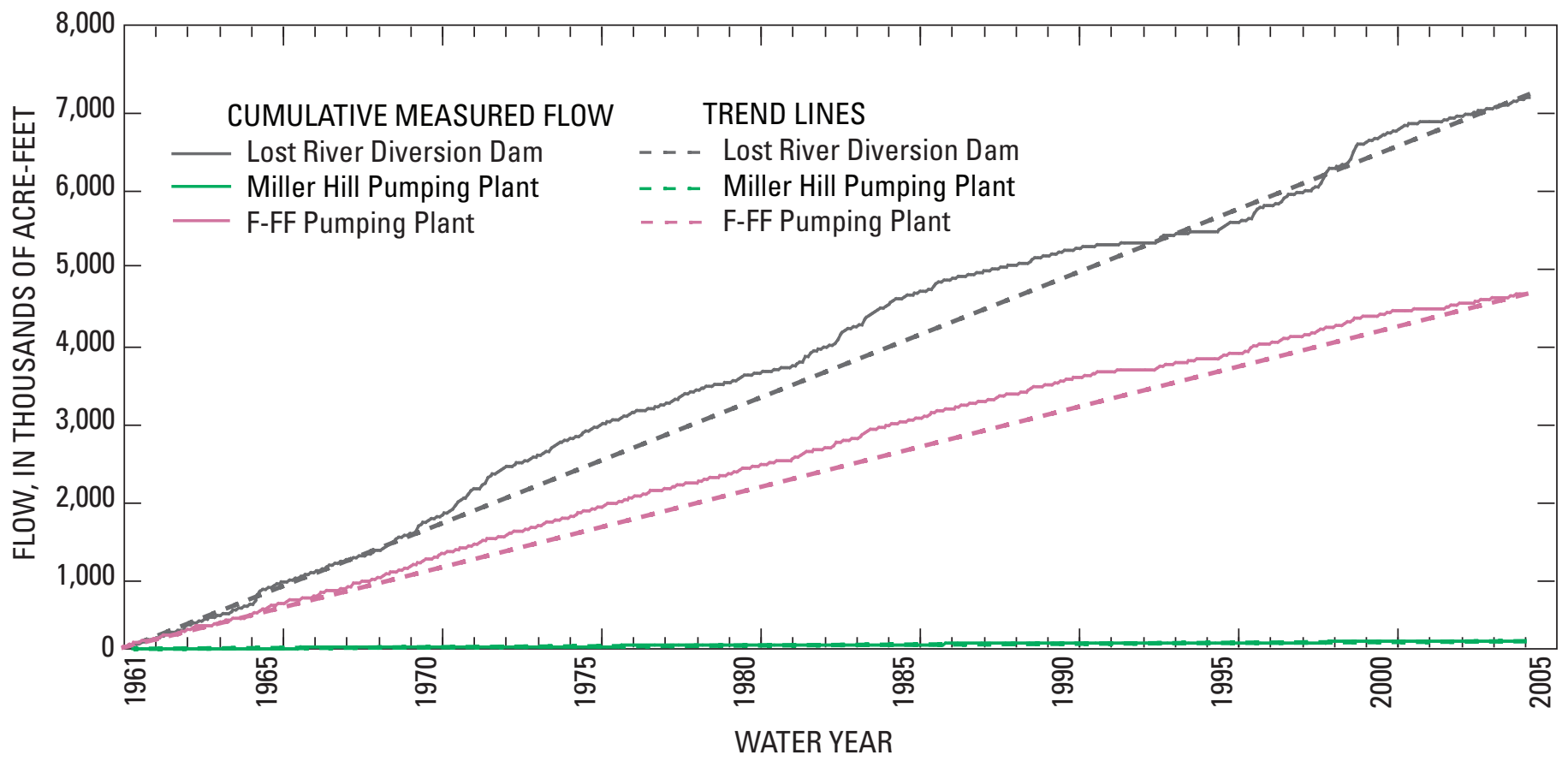

Figure 13. Cumulative monthly canal return flows for the water-balance reach of the Klamath River, south-central Oregon, water years 1961-2004.

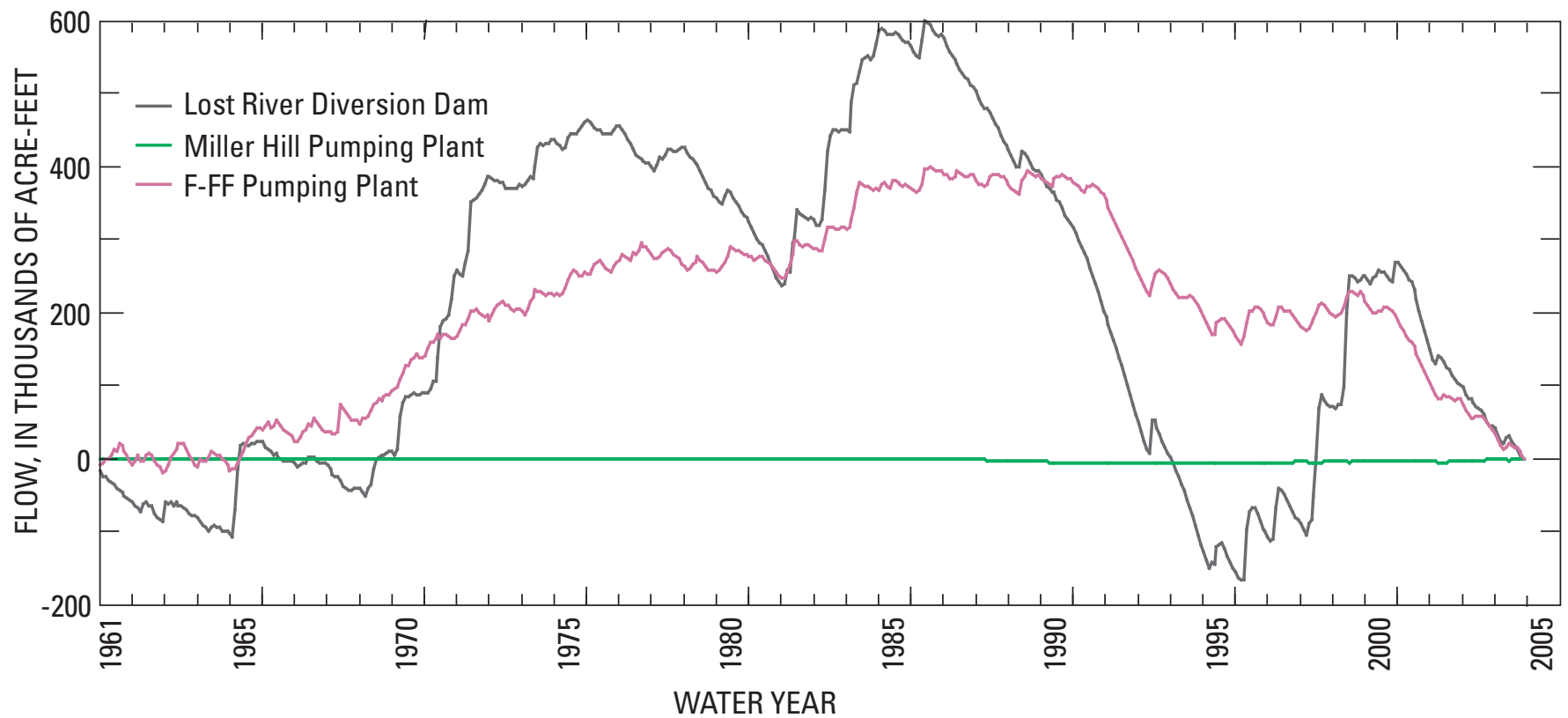

Figure 14. Cumulative residual monthly canal return flows for the water-balance reach of the Klamath River, south-central Oregon, water years 1961-2004. 
in the upper Klamath Basin region. During wet periods (early 1970 s, early 1980s, and late 1990s), a significant portion of the return flows included storm runoff. Likewise, during dry periods (late 1970s, late 1980s to early 1990s, early 2000s), return flows were lower. However, the F-FF Pumping Plant plots, and to a lesser extent the diversion at Lost River Diversion Dam plots, also show a definite overall change in water use over the 44-year period. For the period after the mid1980s, flows at both sites were reduced compared with the previous period from 1961 to the mid-1980s. Flows at the Lost
River Diversion Channel at Lost River Diversion Dam and the F-FF Pumping Plant decreased by about 31,000 and 27,000 acre-ft/yr, respectively, for the 1983-2004 period compared with the 1961-82 period (table 8).

Several of the decreased flows in the 1983-2004 record for the Lost River Diversion Channel at Lost River Diversion Dam (relative to flows in the 1961-82 record) occurred in summer and autumn (table 8). Many farms upstream of the Lost River Diversion Dam in the Poe and Langell valleys had converted from flood to sprinkler irrigation by the early 1980s.

Flows in the Lost River into Lost River Diversion Dam would be expected to decrease during the summer-autumn irrigation season because return flows from sprinkler irrigated fields are significantly less than return flows from flood-irrigated fields (Jerry Pyle, Tulelake Irrigation District, Tulelake, California, oral commun., 2005).

Decreased summer and autumn flows mostly starting in the 1980s are also evident in the Straits Drain at F-FF Pumping Plant flow record (fig. 9C). After construction of the FF pumping plant in 1979 , it was possible to control water levels in the Lower Klamath Wildlife Refuge in a more deliberative manner than in the past. More water was held in the refuge for autumn and winter flooding. As a result, autumn and winter flows decreased in the Straits Drain (John Hicks, Bureau of Reclamation, Klamath Falls, oral commun., 2005). Also, starting in 1992, more water was retained in the Tule Lake Wildlife Refuge as the water levels in Sump 1A and $1 \mathrm{~B}$ were raised because of Endangered Species Act requirements, and less water was pumped over to the Lower Klamath Wildlife Refuge. 


\section{Link River at Klamath Falls}

The cumulative monthly Link River flows for water years 1961-2004 are shown in figure 15. Similar to the cumulative canal return flows, trend fluctuations that mirror the historical wet and dry periods are apparent. A comparison of flows during the last 20 years with the first 24 years of the 1961-2004 period indicates an overall decrease in flows during the last 20 years (fig. 15). This is partly a consequence of flow data error discussed earlier. However, flow changes in the trend plot for the Link River also reflect changes in the management of the Upper Klamath Lake and releases from Link River Dam (Bureau of Reclamation, 2000; 2006). Prior to the 1990s, Link River Dam releases were made in the interest of maintaining sufficient supply for "A" Canal (located above Link River), Lost River Diversion Channel, North Canal, and Ady Canal irrigation diversions and downstream hydropower demands. By the 1990s, Link River releases were also made for the purposes of maintaining minimum lake level elevations and for ensuring sufficient spring and summer downstream flows. As a consequence, winter and early spring Link River Dam releases were significantly reduced in the 1990s compared with earlier decades. More water was held back in Upper Klamath Lake during this part of the year than had been in the past. Aside from Link River, the other main diversion from the lake is through the " $\mathrm{A}$ " Canal at Klamath Falls. Diversions through the "A" Canal have been generally constant over time. They were only slightly decreased, about 8 percent, during water years 1961-82 and 1983-2004 (table 9; fig. 16).

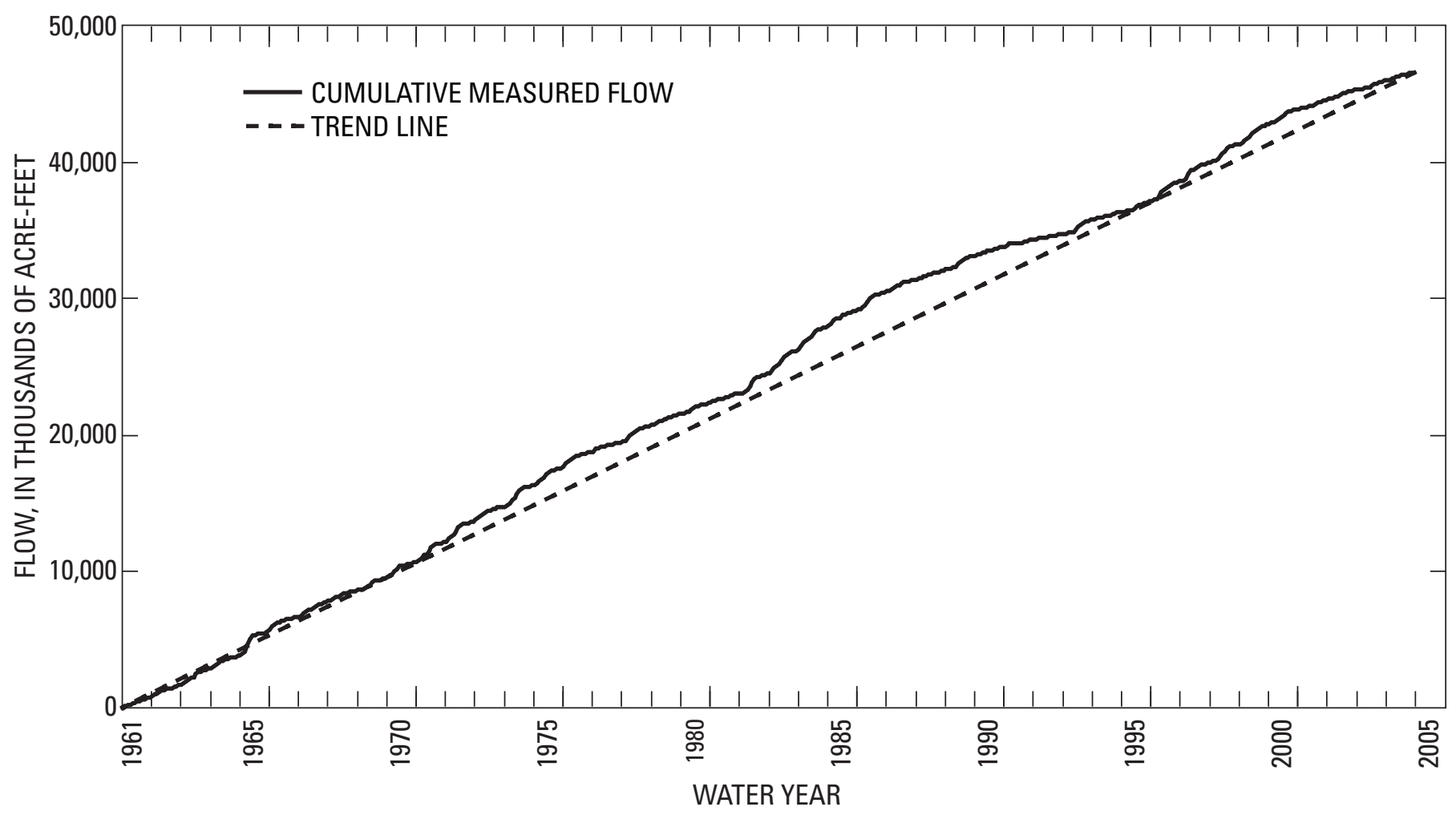

Figure 15. Cumulative monthly flow at Link River at Klamath Falls, south-central Oregon, water years 1961-2004. 


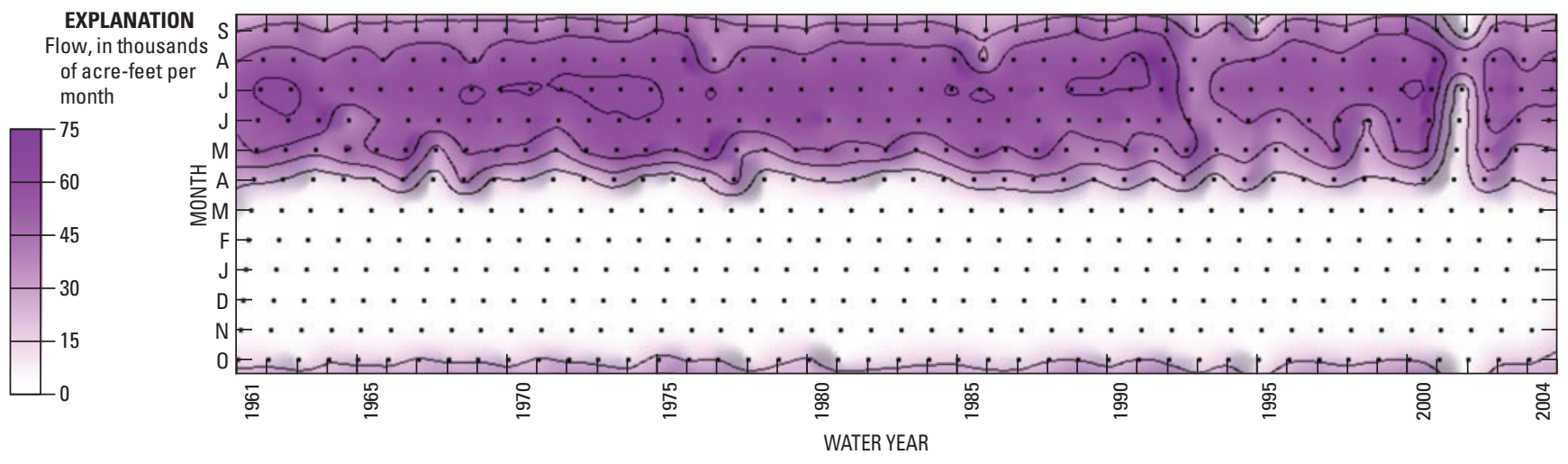

Figure 16. Monthly flow through the "A" Canal at Klamath Falls, south-central Oregon, water years 1961-2004.

Table 9. Mean monthly and mean annual flows through the " $A$ " Canal, Klamath Falls, south-central Oregon, water years 1961-82 and 1983-2004.

[Values in thousand acre-feet]

\begin{tabular}{lrrr}
\hline \multicolumn{1}{c}{ Month } & $\mathbf{1 9 6 1 - 8 2}$ & $\mathbf{1 9 8 3 - 2 0 0 4}$ & Difference \\
\hline October & 11.06 & 10.33 & -0.73 \\
November & .00 & .00 & .00 \\
December & .00 & .00 & .00 \\
January & .00 & .00 & .00 \\
February & .00 & .00 & .00 \\
March & .00 & .03 & .03 \\
April & 14.05 & 17.48 & 3.43 \\
May & 43.87 & 37.55 & -6.32 \\
June & 52.60 & 45.08 & -7.52 \\
July & 59.26 & 52.75 & -6.51 \\
August & 50.92 & 49.34 & -1.58 \\
September & 36.68 & 33.89 & -2.78 \\
\cline { 2 - 4 } Annual & 268.44 & 246.45 & -21.99 \\
\hline
\end{tabular}




\section{Klamath River at Keno}

Another indication of water-management changes in the Klamath Project and the National Wildlife Refuges over the 44-year period can be seen in the USGS flow record for Klamath River at Keno, Oregon (table 10). Mean annual flows for the second 22-year period (water years 1983-2004) were about 109,000 acre-ft less than in the first 22-year period (water years 1961-82). This decrease is not likely an artifact of climate because the two 22-year climate periods were similar (fig. 7). Nor would the decrease be a consequence of flow record quality because this flow record had always been rated as "excellent" or "good." Changes in the operation of Upper Klamath Lake and trends in the canal diversion and return flows would be the most likely explanation for the differences.

Table 10. Mean monthly and mean annual flows for the Klamath River at Keno, south-central Oregon, water years 1961-82 and 1983-2004.

[Values in thousand acre-feet]

\begin{tabular}{lrrr}
\hline \multicolumn{1}{c}{ Month } & $\mathbf{1 9 6 1 - 8 2}$ & $\mathbf{1 9 8 3 - 2 0 0 4}$ & Difference \\
\hline October & 85.92 & 68.41 & -17.51 \\
November & 111.55 & 82.01 & -29.54 \\
December & 148.08 & 102.59 & -45.49 \\
January & 159.86 & 113.11 & -46.75 \\
February & 137.25 & 123.68 & -13.58 \\
March & 166.47 & 174.94 & 8.47 \\
April & 133.03 & 134.40 & 1.37 \\
May & 86.61 & 100.98 & 14.37 \\
June & 31.06 & 56.18 & 25.12 \\
July & 24.23 & 29.62 & 5.39 \\
August & 39.73 & 38.93 & -.80 \\
September & 60.09 & 49.89 & -10.21 \\
\cline { 2 - 4 }$\quad$ Annual & $1,183.87$ & $1,074.72$ & -109.15 \\
\hline
\end{tabular}

\section{Discussion}

As discussed earlier and shown in table 4, the absolute difference (or error) between net water-balance mean annual volumes for the first and second 22-year periods is 103,000 acre-ft. This value can be considered the magnitude of the water-balance inconsistency. Possible reasons for the inconsistency are listed in table 2. For purposes of identifying the cause and source of the water-balance inconsistency in this study, several assumptions can be made:

- Ground-water levels have not increased during the 44year study period. It is unlikely, therefore, that groundwater inflows to the river have increased and that they could be a significant factor in the water-balance inconsistency.

- The magnitude of undocumented diversion and return flows in the study reach (flows not included in the water balance) is insignificant relative to the waterbalance inconsistency.

- The USGS flow record for the Klamath River at Keno, Oregon (the downstream streamflow-gaging station in the water balance), has been rated "excellent" or "good" throughout its history. Error in this record is insignificant relative to the water-balance inconsistency.

- The USGS flow records for the Link River and westside power canal have been rated "excellent" or "good" throughout their history. Although these records were not used in the water balance, they can be used to assess some of the error in the ReclamationPacifiCorp record for the Link River.

On the basis of these assumptions, the probable cause of the water-balance inconsistency is error in the eight diversion and return-flow records. Part of the 103,000 acre-ft waterbalance inconsistency can be explained by an 11,000 acre-ft/yr error in the westside power canal flow record for water years 1984-2004. Another part can be explained by a 32,000 acre-ft error in the river flow portion of the Link River flow record. A residual of 60,000 acre-ft of error could then be distributed among the seven other returns and diversions: the Lost River Diversion Channel Lost River Diversion Dam return, Lost River Diversion Channel Miller Hill Pumping Plant return, Klamath Straits Drain F-FF Pumping Plant return, North Canal diversion, Ady Canal diversion, Lost River Diversion Channel Station 48 diversion, and Lost River Diversion Channel Miller Hill Pumping Plant diversion. Some of the 60,000 acre-ft of error might also be in the Link River flow record; the magnitude of the Link River flow is many times greater than that of the seven other flow magnitudes. Detailed data-collection documentation that could be used to identify specific sources of error during the 44-year period in the seven flow records is unavailable. However, it is notable, or possibly coincidental, that the error bias in all seven flow records is consistent among them and with known water-management changes in the Klamath Project and National Wildlife Refuges. All diversion flows increased over time, and all return flows decreased over time. 


\section{Summary and Conclusions}

A 2005 U.S. Geological Survey (USGS) assessment of the Bureau of Reclamation (Reclamation) Klamath Pilot Water Bank program found inconsistencies in the river and canal flow records from sites along the Klamath River between Klamath Falls and Keno, Oregon, for water years 1961-2004. The sum of flows through eight diversions and returns was subtracted from flows at a downstream streamflow-gaging station to compute a surface-water balance for this reach of the river. Four diversion flows in the equation included Lost River Diversion Channel at Station 48, Lost River Diversion Channel at Miller Hill Pumping Plant, North Canal at U.S. Highway 97, and Ady Canal at U.S. Highway 97. Four return flows in the equation included Link River at Klamath Falls, Lost River Diversion Channel at Lost River Diversion Dam, Lost River Diversion Channel at Miller Hill Pumping Plant, and Klamath Straits Drain at F-FF Pumping Plants. The Klamath River USGS streamflow-gaging station at Keno, Oregon (11509500) was the downstream flow-measurement site for the water-balance equation. The water balance showed that the study reach was losing flow in the 1960s and 1970s, and gaining flow in 1980s and 1990s. For the first and second 22-year periods (water years 1961-82 and 1983-2004), the mean annual net water-balance flows were $-68,000$ and 35,000 acre-feet (acre-ft), respectively. The absolute difference in flows between the two periods was 103,000 acre-feet per year (acre-ft/yr).

Possible explanations for the water-balance inconsistency between the early and late periods include (1) error in the flow-data records included in the water balance, (2) changes in undocumented surface-water inflows and outflows not included in the water balance, and (3) changes in ground-water exchange with the river.

In this study, the data quality of all flow records used in the water balance was evaluated using USGS criteria for flow accuracy. With the exception of the USGS Klamath River at Keno record, which was rated as "good" or "excellent," the eight other flow records were rated as "poor." All eight flow records were from non-USGS sites and had insufficient data-collection documentation. Other than for the Link River flow record, there was no evidence of abrupt changes in data-collection procedures in the flow records during the 44-year period that could have explained the water-balance inconsistency. The Reclamation-PacifiCorp Link River record included both river and westside power canal flows. Because of rating curve biases, the river flows could have been overestimated by 25,000 acre-ft/yr on average during water years 1961-82, and underestimated by 7,000 acre-ft/yr on average during water years 1983-2004. For water years 19842004 , the canal flows were in error by about 11,000 acre-ft/yr.
These errors in the Link River flow record (combined river and canal) explained part, but not all, of the water-balance inconsistency.

Smaller undocumented surface-water diversion and return flows along the Klamath River that were in the study area reach and not included in the water-balance equation were evaluated. These diversion flows included individual withdrawals from the Klamath River for irrigation and industrial use. Return flows included drainage from irrigation, storm runoff, discharge from wood-products processing plants, and effluent from wastewater-treatment plants. There was no evidence of abrupt changes in the flows of these diversions and returns that could have explained the water-balance inconsistency. The cumulative magnitude of the undocumented flows also was too small to explain the inconsistency.

Climate data and ground-water level data from wells in or near the study reach did not show an increasing trend during the 44-year period of record that would have caused an increase in ground-water discharge to the river mean annual water year precipitation at Klamath Falls for 1961-82 and 1983-2004 was 13.3 and 13.8 in., respectively, which is a difference of less than 5 percent.

Trends in the eight diversion and return-flow records used in the water balance were evaluated to determine whether known changes in water-management practices in the Klamath Project and Lower Klamath and Tule Lake National Wildlife Refuges during the 44-year period are evident in the flow data. Although trends related to water management cannot explain water-balance inconsistencies (the same trends would be reflected in the most downstream flow record, Klamath River at Keno), the analysis was included to determine whether management changes were apparent in the flow data and whether possible data error could be detected by noting inconsistencies among measurement sites. Many of the watermanagement changes were implemented in the early 1980s. Mean annual diversion flows at Station 48, North Canal, and Ady Canal during water years 1983-2004 increased over $1961-82$ by $16,000,8,000$, and 21,000 acre-ft/yr, respectively. Conversion from flood to sprinkler irrigation actually increased total irrigation use in some of the lands serviced by these canals by enabling production of crops with a higher consumptive use. Additionally, summer crop production was implemented in some fields that had been used solely for winter wheat production. Some of the increased Station 48 and Ady Canal flows were also used to accommodate increased water use in both the Lower Klamath and Tule Lake refuges. The conversion from flood to sprinkler irrigation also resulted in a significant reduction in return flows in the 1980s and 1990s. Mean annual flows at the Lost River Diversion Channel at Lost River Diversion Dam and the Klamath Straits Drain at F-FF Pumping Plant for water years 1983-2004 decreased by 31,000 and 27,000 acre-ft, respectively, compared with water 
years 1961-82. Releases through the Link River Dam in the 1990s also were reduced to maintain minimum lake elevations for fish habitat.

The probable cause of the water-balance inconsistency was error in the eight diversion and return-flow data records; however, data-collection documentation during the 44-year period was insufficient to determine which flow record, or records, contained most of the error. Some of the 103,000 acre-ft water-balance inconsistency can be explained by a 32,000 acre-ft error in the river flow portion of the Link River flow record. Another portion can be explained by an $11,000 \mathrm{acre}-\mathrm{ft} / \mathrm{yr}$ error in the westside power canal flow record, included in the Link River flow record, for water years 1984-2004. The cause of the remaining 60,000 acre-ft of error could not be determined. Some of it could still be in the Reclamation-PacifiCorp flow record for the Link River, and some might be distributed among the seven other flow records. Coincidentally, the error bias in all eight flow records was consistent among the sites and with known water-management changes in the Klamath Project and National Wildlife Refuges.

From the analysis of flow data in this study, it is evident that an improved water measurement network is warranted to better understand both natural and anthropogenic impacts on the hydrologic system. In particular, this analysis described errors in the Link River flow record that can be corrected in Reclamation's hydrologic database to ensure that any historic analyses of these data and the computation of Upper Klamath Lake monthly net inflows are based on sound hydrologic data.

\section{Acknowledgements}

The authors thank Jon Hicks, Bureau of Reclamation, Klamath Falls; John Rasmussen, formerly with the Bureau of Reclamation, Klamath Falls, Oregon; Beau Freeman, Irrigation Training and Research Center, California Polytechnic State University, San Luis Obispo, California, and Daniel Snyder, USGS Oregon Water Science Center for their assistance in this study.

\section{References Cited}

Broad, T.M., and Collins, C.A., 1996, Estimated water use and general hydrologic conditions for Oregon, 1985 and 1990:

U.S. Geological Survey Water-Resources Investigations

Report 96-4080, 166 p.
Bureau of Reclamation, 2000, Klamath project historic operation: United States Department of the Interior, Bureau of Reclamation, Mid-Pacific Region, Klamath Basin Area Office, 98 p.

Bureau of Reclamation, 2006, Welcome to the Klamath Basin Area Office: http://www. usbr.gov/mp/kbaol, modified May 24, 2006, accessed on May 25, 2006.

Burt, C., and Freeman, B., 2003, Klamath Basin investigation-Hydrologic assessment of the Upper Klamath Basin, Issues and opportunities, Draft report, May 2003: San Luis Obispo, California, Irrigation Training and Research Center, California Polytechnic State University, 274 p.

Freeman, B., Hicks, J., and Burt, C., 2005, Leveraging SCADA to modernize operations in the Klamath irrigation project, in Proceedings of the SCADA and Related Technologies for Irrigation District Modernization Conference, Vancouver, Washington, October 26-29, 2005: The U.S. Society for Irrigation and Drainage Professionals, Denver, Colorado, $14 \mathrm{p}$.

PacifiCorp, 2005, Klamath River water quality model implementation, calibration, and validation, Klamath Hydroelectric Project (FERC Project No. 2082), Response to November 10, 2005, FERC AIR GN-2, (Version: Dec. 2005, Dec. 16, 2005, FERC filing): Portland, Oregon, PacifiCorp, $455 \mathrm{p}$.

Sammuel, E.A., 1980, Hydrogeological appraisal of the Klamath Falls geothermal area: U.S. Geological Survey Professional Paper 1044-G, 45 p.

U.S. Census Bureau, 2005, Census Bureau home page: http:// www.census.gov, accessed July 5, 2005. 
Manuscript approved for publication, August 17, 2006

Prepared by the USGS Publishing Network,

Publishing Service Center, Tacoma, Washington

Bill Gibbs

Linda Rogers

Bobbie Jo Richey

For more information concerning the research in this report, contact the Director, Oregon Water Science Center

U.S. Geological Survey

10615 SE Cherry Blossom Drive

Portland, Oregon 97216

http://or.water.usgs.gov 


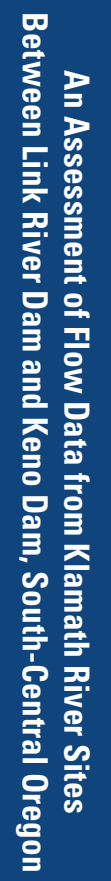

